M. Cakmak, I.I. Ozturk*, C.N. Banti*, M. Manoli, E. Moushia , A.J. Tasiopoulos, A.M. Grześkiewicz, M. Kubicki and S.K. Hadjikakou*

\title{
Bismuth(III) bromide-thioamide complexes: synthesis, characterization and cytotoxic properties
}

https://doi.org/10.1515/mgmc-2018-0035

Received June 23, 2018; accepted August 13, 2018; previously published online September 21, 2018

Abstract: New bismuth(III) bromine compounds of the heterocyclic thioamides were prepared and structurally characterized. The reaction of heterocyclic thioamides with bismuth(III) bromide resulted in the formation of the $\left\{\left[\mathrm{BiBr}_{2}\left(\mu_{2}-\mathrm{Br}\right)(\mathrm{MMI})_{2}\right]_{2} \cdot \mathrm{CH}_{3} \mathrm{COCH}_{3} \cdot \mathrm{H}_{2} \mathrm{O}\right\}$ (1), $\quad\left\{\left[\mathrm{BiBr}_{2}(\mathrm{MBZIM})_{4}\right] \cdot \mathrm{Br} \cdot 2 \mathrm{H}_{2} \mathrm{O}\right\} \quad(2), \quad\left\{\left[\mathrm{BiBr}_{2}\left(\mu_{2}-\mathrm{Br}\right)\right.\right.$ (tHPMT) $\left.]_{2} \cdot \mathrm{CH}_{3} \mathrm{CN}\right\} \quad(3), \quad\left\{\left[\mathrm{BiBr}_{2}\left(\mu_{2}-\mathrm{Br}\right)(\mathrm{PYT})_{2}\right]_{2} \cdot \mathrm{CH}_{3} \mathrm{CN}\right\}$ (4) and $\left\{\left[\mathrm{BiBr}_{2}\left(\mu_{2}-\mathrm{Br}\right)(\mathrm{MBZT})_{2}\right]_{2} 2 \mathrm{CH}_{3} \mathrm{OH}\right\}$ (5) complexes (MMI: 2-mercapto-1-methylimidazole, MBZIM: 2-mercaptobenzimidazole, tHPMT: 2-mercapto-3,4,5,6-tetrahydro-pyrimidine, PYT: 2-mercaptopyridine and MBZT: 2-mercaptobenzothiazole). The complexes 1-5 were characterized by melting point (m.p.), elemental analysis (e.a.), molar conductivity, Fourier-transform infrared (FT-IR), Fourier-transform Raman (FT-Raman), nuclear magnetic resonance $\left({ }^{1} \mathrm{H}\right.$ and $\left.{ }^{13} \mathrm{CNMR}\right)$ spectroscopy, UV-Vis spectroscopy and thermogravimetric-differential thermal analysis (TG-DTA). The molecular structures of 1-5 were determined by single-crystal X-ray diffraction. Complex 2 is a first ionic monomuclear octahedral bismuth(III) bromide, while the complexes 1, 3-5 are the first examples of dinuclear bismuth(III) bromide derivatives. Complexes 1-5 were evaluated in terms of their in vitro cytotoxic activity

apresent address: Department of Life Sciences, The School of Sciences, European University Cyprus, 1516 Nicosia, Cyprus. *Corresponding authors: I.I. Ozturk, Department of Chemistry, Namık Kemal University, Tekirdag 59030, Turkey,

e-mail: iiozturk@nku.edu.tr; and C.N. Banti and S.K. Hadjikakou, Section of Inorganic and Analytical Chemistry, Department of Chemistry, University of Ioannina, Ioannina 45110, Greece, e-mail: cbanti@cc.uoi.gr (C.N. Banti); shadjika@uoi.gr (S.K. Hadjikakou)

M. Cakmak: Department of Chemistry, Namık Kemal University, Tekirdag 59030, Turkey

M. Manoli, E. Moushi and A.J. Tasiopoulos: Department of Chemistry, University of Cyprus, Nicosia 1678, Cyprus

A.M. Grześkiewicz and M. Kubicki: Department of Chemistry, A. Mickiewicz University, ul. Umultowska 89b, Poznan 61-614, Poland against human adenocarcinoma breast (MCF-7) and cervix (HeLa) cells. The toxicity on normal human fetal lung fibroblast cells (MRC-5) was also evaluated. Moreover, the complexes 1-5 and free heterocyclic thioamide ligands were studied upon the catalytic peroxidation of the linoleic acid by the enzyme lipoxygenase (LOX).

Keywords: biological inorganic chemistry; bismuth(III) bromide; cytotoxicity; thioamides.

\section{Introduction}

Presently, the medicinal application of bismuth(III) compounds is focused on the antibacterial and anticancer metallodrugs (Yang and Sun, 2007). Thus, bismuth(III) halide ditihocarbamate complexes of the general formula $\operatorname{BiX}_{n}\left(\mathrm{~S}_{2} \mathrm{CNR}_{2}\right)_{3-n},(n=0,1$ and $2, \mathrm{X}=\mathrm{Cl}, \mathrm{Br}$ or I) have proven to display extremely strong cytotoxic activity against human breast adenocarcinoma (MCF-7) cells, while their $\mathrm{IC}_{50}$ values lie in the range of nanomolar (Ozturk et al., 2014a,b; Arda et al., 2016). Bismuth(III) thiosemicarbazone complexes also showed effective cytotoxic activity against cancerous cell lines (Li et al., 2012a,b; Zhang et al., 2014).

The enzyme lipoxygenase (LOX) participates in the mechanism of inflammation, catalyzing the oxidation of arachidonic acid to leukotrienes in an essential mechanism for cell life (Xanthopoulou et al., 2008; Ozturk et al., 2010; Poyraz et al., 2011). LOX has been investigated as a potent target for the development of new metallodrugs against cancerous cells as it has been associated with the antiproliferative activity by the induction of apoptosis in tumor cells (Poyraz et al., 2011).

In the course of our studies towards the development of effective chemotherapeutics agents (Hadjikakou et al., 2005; Ozturk et al., 2007, 2009, 2010, 2011, 2012a,b, 2013, 2014a,b, 2017; Xanthopoulou et al., 2008; Balas et al., 2011; Poyraz et al., 2011; Shpakovsky et al., 2012; Banti et al., 2016; Urgut et al., 2016a,b; Yarar et al., 2018) we describe here the synthesis and characterization of the complexes $\left\{\left[\mathrm{BiBr}_{2}\left(\mu_{2}-\mathrm{Br}\right)(\mathrm{MMI})_{2}\right]_{2} \cdot \mathrm{CH}_{3} \mathrm{COCH}_{3} \cdot \mathrm{H}_{2} \mathrm{O}\right\}$ (1), $\quad\left\{\left[\mathrm{BiBr}_{2}(\mathrm{MBZIM})_{4}\right] \cdot \mathrm{Br} \cdot 2 \mathrm{H}_{2} \mathrm{O}\right\} \quad(2), \quad\left\{\left[\mathrm{BiBr}_{2}\left(\mu_{2}-\mathrm{Br}\right)\right.\right.$ 
(tHPMT) $\left.\left.]_{2}\right]_{2} \cdot \mathrm{CH}_{3} \mathrm{CN}\right\}$ (3), $\left\{\left[\mathrm{BiBr}_{2}\left(\mu_{2}-\mathrm{Br}\right)(\mathrm{PYT})_{2}\right]_{2} \cdot \mathrm{CH}_{3} \mathrm{CN}\right\}$ (4) and $\left\{\left[\mathrm{BiBr}_{2}\left(\mu_{2}-\mathrm{Br}\right)(\mathrm{MBZT})_{2}\right]_{2} \cdot 2 \mathrm{CH}_{3} \mathrm{OH}\right\}$ (5) using the heterocyclic thioamide ligands (Scheme 1). In order to rationalize the hindrance due to steric effects and the electronic factors that govern the biological activity, many compounds of the main group of metal ions (Sn(IV), Sb(III/IV), Bi(III) etc.) (Hadjikakou et al., 2005; Ozturk et al., 2007, 2009, 2010, 2011, 2012a,b, 2013, 2014a,b, 2017; Xanthopoulou et al., 2008; Balas et al., 2011; Poyraz et al., 2011; Shpakovsky et al., 2012; Banti et al., 2016; Urgut et al., 2016a,b; Yarar et al., 2018) with various types of ligands, such as Thioamides, Dithiocarbametes, the Non-Steroidal Anti-inflammatory Drugs (NSAID), aspirin, salicylic acid, naproxen, etc. were synthesized and characterized.

The present manuscript describes the recent results obtained in bismuth(III) bromide. These results are compared with those previously reported from our group in relation with the drug cisplatin, which is in clinical use (Table 2). Conclusions will be attempted upon changing either the halogen counter anion $(\mathrm{Cl}, \mathrm{Br}$ and $\mathrm{I})$ or the ligand type (thioamides, dithiocarbamates). Among thioamides, the electronic effect is arising from thiourea derivatives with 5-member ring imidazole, benzimidazole and benzothiazle and 6-member ring tetrahydro pyrimidine and pyridine (Scheme 1). The in vitro cytotoxicity of the compounds was tested against the cancerous and noncancerous cell lines. The antioxidant behaviors of these compounds are also evaluated with their influence upon the catalytic peroxidation of linoleic acid by the enzyme of lipoxygenase (LOX).

\section{Results and discussion}

\section{General aspects}

The reactions of bismuth(III) bromide with the heterocyclic thioamides (MMI: 2-mercapto-1-methylimidazole, MBZIM: 2-mercaptobenzimidazole, tHPMT: 2-mercapto3,4,5,6-tetrahydro-pyrimidine, PYT: 2-mercaptopyridine, MBZT: 2-mercaptobenzothiazole) in 1:2 (M:L) molar ratio, result in the isolation of the complexes $\left\{\left[\operatorname{BiBr}_{2}\left(\mu_{2}-\mathrm{Br}\right)\right.\right.$ $\left.\left.(\mathrm{MMI})_{2}\right]_{2} \cdot \mathrm{CH}_{3} \mathrm{COCH}_{3} \cdot \mathrm{H}_{2} \mathrm{O}\right\}(\mathbf{1}),\left\{\left[\mathrm{BiBr}_{2}(\mathrm{MBZIM})_{4}\right] \cdot \mathrm{Br} \cdot 2 \mathrm{H}_{2} \mathrm{O}\right\}$ (2), $\quad\left\{\left[\mathrm{BiBr}_{2}\left(\mu_{2}-\mathrm{Br}\right)(\mathrm{tHPMT})_{2}\right]_{2} \cdot \mathrm{CH}_{3} \mathrm{CN}\right\} \quad$ (3), $\quad\left\{\left[\mathrm{BiBr}_{2}\left(\mu_{2}-\mathrm{Br}\right)\right.\right.$ $\left.\left.(\mathrm{PYT})_{2}\right]_{2} \cdot \mathrm{CH}_{3} \mathrm{CN}\right\}$ (4) and $\left\{\left[\mathrm{BiBr}_{2}\left(\mu_{2}-\mathrm{Br}\right)(\mathrm{MBZT})_{2}\right]_{2} \cdot 2 \mathrm{CH}_{3} \mathrm{OH}\right\}$ (5) (Scheme 2). Crystals of 1-5, which are suitable for X-ray diffraction (XRD), were grown through the slow evaporation of the solutions. The compounds were characterized by e.a., FT-IR, FT-Raman, ${ }^{1} \mathrm{H},{ }^{13} \mathrm{C}$ NMR, UV, TG-DTA and single crystal by XRD crystallography.

\section{Vibrational spectroscopy}

The characteristic vibration bands of 1-5 and their ligands are summarized in Table S1. Significant changes between<smiles>Cn1cc[nH]c1=S</smiles>

MMI<smiles>S=c1[nH]c2ccccc2[nH]1</smiles>

MBZIM

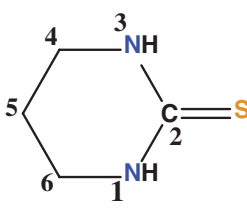

tHPMT

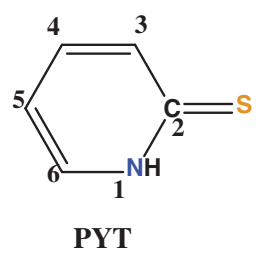<smiles>S=c1[nH]c2ccccc2s1</smiles>

Scheme 1: The molecular formulae of thioamide ligands used in this work.

$$
\begin{aligned}
& 4 \mathrm{MMI}+2 \mathrm{BiBr}_{3} \stackrel{\text { Acetone }}{\longrightarrow}\left\{\left[\mathrm{BiBr}_{2}\left(\mu_{2}-\mathrm{Br}\right)(\mathrm{MMI})_{2}\right]_{2} \mathrm{CH}_{3} \mathrm{COCH}_{3} \mathrm{H}_{2} \mathrm{O}\right\}
\end{aligned}
$$

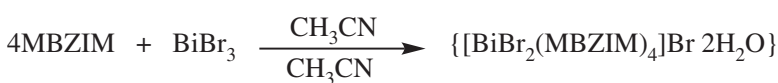

$$
\begin{aligned}
& 4 \mathrm{tHPMT}+2 \mathrm{BiBr}_{3} \underset{\mathrm{CH}_{3} \mathrm{OH}}{\stackrel{\mathrm{CH}_{3} \mathrm{OH}}{\longrightarrow}}\left\{\left[\mathrm{BiBr}_{2}\left(\mu_{2}-\mathrm{Br}\right)(\mathrm{tHPMT})_{2}\right]_{2} \mathrm{CH}_{3} \mathrm{CN}\right\}
\end{aligned}
$$

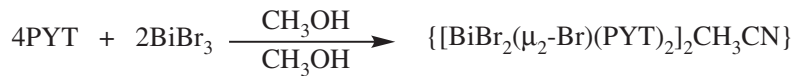

$$
\begin{aligned}
& 4 \mathrm{MBZT}+2 \mathrm{BiBr}_{3} \underset{\mathrm{CH}_{3} \mathrm{OH}}{\stackrel{\text { Benzene }}{\longrightarrow}}\left\{\left[\mathrm{BiBr}_{2}\left(\mu_{2}-\mathrm{Br}\right)(\mathrm{MBZT})_{2}\right]_{2} 2 \mathrm{CH}_{3} \mathrm{OH}\right\}
\end{aligned}
$$

Scheme 2: The synthesis of bismuth(III) bromide complexes with thioamides (1-5). 
the IR spectra of the complexes towards their ligands were observed. The IR spectra of $\mathbf{1 - 5}$ show distinct vibrational bands at 1468-1284 (1), 1491-1346 (2), 1595-1203 (3), 1508-1124 (4) and 1491-1331 $\mathrm{cm}^{-1}$ (5), respectively, which are attributed to the $v(\mathrm{CN})$ vibrations (Thioamide I and II bands) (Supplementary Figures S1-S5). The vibration bands at 1088-742 (1), 1005-752/741 (2), 1111-623 (3), 1034-721 (4) and 1007-600 $\mathrm{cm}^{-1}$ (5) are assigned to the $v(\mathrm{CS})$ vibrations (Thioamide III and IV bands) (Figures $\mathrm{S} 1-\mathrm{S} 5)$. The amide $\mathrm{N}-\mathrm{H}$ bond stretching vibrations were observed in the region of $3265-3068 \mathrm{~cm}^{-1}$ in 1-5 (Figures S1-S5). The corresponding thioamide bands of the free ligands are 1456, 1273, 1084 and $737 \mathrm{~cm}^{-1}$ for MMI; 1508, 1354, 1014 and $694 \mathrm{~cm}^{-1}$ for MBZIM; 1552, 1192, 1065 and $642 \mathrm{~cm}^{-1}$ for tHPMT; 1570, 1254, 1132 and $727 \mathrm{~cm}^{-1}$ for PYT and 1495, 1319, 1032 and $667 \mathrm{~cm}^{-1}$ for MBZT (Ozturk et al., 2007, 2009, 2010) (Figures S6-S10).

Further information about the bonding type of 1-5 was obtained by FT-Raman spectroscopy (Ozturk et al., 2007, 2009, 2010, 2011, 2012a,b, 2013, 2014a,b, 2017; Urgut et al., 2016a,b; Yarar et al., 2018) (Supplementary Table S1, Figures S11-S15). The metal-sulfur vibration bands can be found between 200 and $350 \mathrm{~cm}^{-1}$ (Ozturk et al., 2007, 2009, 2010, 2011, 2012a,b, 2013, 2014a,b, 2017; Urgut et al., 2016a,b; Yarar et al., 2018). The new peaks at 234 (1), 205 (2), 231 (3), 253 (4) and $228 \mathrm{~cm}^{-1}(5)$ are assigned at the Bi-S bond. The terminal Bi-Br vibration band appears at 187 (1), 148 (2), 162 (3), 165 (4) and $203 \mathrm{~cm}^{-1}$ (5), respectively. The bands at 168 (1), 142 (3), 145 (4) and $178 \mathrm{~cm}^{-1}$ (5) are attributed to the $\mathrm{Bi}-\mathrm{Br}$ terminal bond. The bridging $\mathrm{Bi}-\mathrm{Br}$-Bi vibration bands for 1-5 appear at 105 (1), 108 (3), 117 (4) and $139 \mathrm{~cm}^{-1}$ (5), respectively. On the one hand, compound $\mathbf{2}$ is monomeric as the terminal $\mathrm{Bi}-\mathrm{Br}$ and the $\mathrm{Bi}-\mathrm{S}$ vibrations bands appeared in the Raman spectrum. Complexes 1, 3-5 on the other hand, have bridging $\mathrm{Bi}-\mathrm{Br}-\mathrm{Bi}$ vibration bands and terminal vibrations; therefore, they are classified as dimmers.

Given that the assignment of the vibrational spectra of 1-5 was made using the molecular structures, which were determined from the single crystal XRD data (see Section 'Crystal and molecular structures'), the retention of the formulae is deduced in the solid state for these samples. This is required for the samples' purity verification.

\section{TG-DTA analysis}

The thermal stability of 1-5 was analyzed by thermal gravimetry-differential thermal analysis (TG-DTA) under nitrogen atmosphere (Figure S16). After the releasing of the solvents from the crystal lattice, complexes 1-5 are stable up to $206^{\circ} \mathrm{C} \mathrm{(1),} 270^{\circ} \mathrm{C} \mathrm{(2),} 150^{\circ} \mathrm{C}(\mathbf{3}), 120^{\circ} \mathrm{C}$ (4) and $150^{\circ} \mathrm{C}$ (5), respectively. The corresponding TG-DTA diagrams for compounds $1-5\left(206^{\circ} \mathrm{C}-940^{\circ} \mathrm{C}\right)(\mathbf{1}), 100^{\circ} \mathrm{C}-825^{\circ}$ $\mathrm{C}(2), 106^{\circ} \mathrm{C}-983^{\circ} \mathrm{C}(3), 110^{\circ} \mathrm{C}-983^{\circ} \mathrm{C}(4)$ and $128^{\circ} \mathrm{C}-983^{\circ} \mathrm{C}$ (5)) involve 100\% (1), 98.91\% (2), 97.95\% (3), 100\% (4) and 97.20\% (5) mass losses, respectively.

\section{UV-Vis spectroscopy}

The UV-Vis absorption spectra of the heterocyclic thioamide ligands as well as the corresponding ones of their bismuth(III) bromide complexes 1-5 were recorded in the DMSO solution (Figure S17). The absorption bands for complexes 1, 3 and $\mathbf{4}$ were observed around $300-450 \mathrm{~nm}$, which can be attributed to the intra-ligand electrons' transitions.

\section{NMR spectroscopy}

The ${ }^{1} \mathrm{H}$ and ${ }^{13} \mathrm{C}$-NMR spectra of $\mathbf{1 - 5}$ and their ligands (Figures S18-S37) were recorded in DMSO- $d_{6}$. Their chemical shifts are summarized in Table S2. The resonance signals at 12.26 (1), 12.57 (2), 8.07 (3), 13.66 (4) and 13.80 ppm (5), respectively (Figures S18-S27), are attributed to the amine protons of 1-5. The ${ }^{1} \mathrm{H}$ NMR chemical shift values of 1-5 are almost similar to those of the corresponding ligands. The ${ }^{13} \mathrm{C}(>\mathrm{C}=\mathrm{S})$ resonance signals in the ${ }^{13} \mathrm{C}$ NMR spectra of $\mathbf{1 - 5}$ are observed at 159.57 (1), 168.92 (2), 174.11 (3), 176.43 (4) and $190.72 \mathrm{ppm}$ (5), respectively (Figures S28-S37). The ${ }^{13} \mathrm{C}$ NMR spectra of 1-5 showed the 1-3 ppm up-field shift for the $C=S$ carbon due to complexation. Small shifts in the NMR spectra were also observed for antimony(III) complexes with thioamides or thiones (Ozturk et al., 2011, 2012a,b, 2013, 2014a,b, 2017; Urgut et al., 2016a,b; Yarar et al., 2018).

The assignment of the NMR spectra in the solution was again made using the molecular structures (see Section 'Crystal and molecular structures'), and therefore, the retention of the formulae is deduced in the solutions. This is required for the further biological studies.

\section{Crystal and molecular structures of $\left\{\left[\mathrm{BiBr}_{2}\left(\mu_{2}-\mathrm{Br}\right)(\mathrm{MMI})_{2}\right]_{2} \cdot \mathrm{CH}_{3} \mathrm{COCH}_{3} \cdot \mathrm{H}_{2} \mathrm{O}\right\}$ (1), $\left\{\left[\mathrm{BiBr}_{2}(\mathrm{MBZIM})_{4}\right] \cdot \mathrm{Br} \cdot 2 \mathrm{H}_{2} \mathrm{O}\right\}$ (2), $\left\{\left[\mathrm{BiBr}_{2}\left(\mu_{2}-\mathrm{Br}\right)(\mathrm{tHPMT})_{2}\right]_{2} \cdot \mathrm{CH}_{3} \mathrm{CN}\right\}$ (3), $\left\{\left[\mathrm{BiBr}_{2}\left(\mu_{2}-\mathrm{Br}\right)(\mathrm{PYT})_{2}\right]_{2} \cdot \mathrm{CH}_{3} \mathrm{CN}\right\}$ (4) and $\left\{\left[\mathrm{BiBr}_{2}\left(\mu_{2}-\mathrm{Br}\right)(\mathrm{MBZT})_{2}\right]_{2} \cdot 2 \mathrm{CH}_{3} \mathrm{OH}\right\}$ (5)}

Structural reports on bismuth(III) bromide complexes with ligands containing sulfur donor atoms (either thiones 
or thioureas) are already known ( $\mathrm{Li}$ and $\mathrm{Li}, 2014$; Srinivas et al., 2015, 2016). Bismuth(III) bromide complexes with thione adopt octahedral $\left(\mathrm{O}_{\mathrm{h}}\right)$, square pyramidal (SP) and pseudo-trigonal bipyramidal ( $\psi$-TBP) geometries. The pseudo-trigonal bipyramidal bismuth(III) bromide complexes have a mononuclear core (e.g. [(IPr $=\mathrm{S})$ $\left.\mathrm{BiBr}_{3}\right] \cdot \mathrm{CHCl}_{3}$ (Srinivas et al., 2015)), while the octahedral and square pyramidal bismuth(III) bromide complexes have a binuclear core (e.g. $\left[(\mathrm{mbit}) \operatorname{Bi}(\mathrm{Br})_{2}\left(\mu_{2}-\mathrm{Br}\right)_{2}\right]$ (mbit: 3,3'-methylenebis(1-methyl-1H-imidazol-3-ium), [(mbpit) $\left.\mathrm{Bi}(\mathrm{Br})_{2}\left(\mu_{2}-\mathrm{Br}\right)\right]_{2} \cdot \mathrm{CH}_{3} \mathrm{CN}$ (mbpit: 3,3'-methylenebis(1-isopropyl-1 $H$-imidazol-3-ium), $\quad\left[(\mathrm{IMesS}) \mathrm{Bi}(\mathrm{Br})_{2}\left(\mu_{2}-\mathrm{Br}\right)\right]_{2} \cdot 4 \mathrm{CHCl}_{3}$ (Srinivas et al., 2016).

Binuclear bismuth(III) complexes with octahedral geometry exhibit four different stereoisomers (Scheme 3), (a) those with two sulfur atoms and two halogen atoms in the cis-orientation and two bismuth atoms bridged to each other by two halogen atoms; (b) those with two sulfur atoms in the cis-position and two halogen atoms in transposition to each other, while the two bismuth atoms are bridged by two halogen atoms; (c) those with two sulfur atoms in the trans-position and two halogen atoms in the cis-position, while the two bismuth atoms are connected to each other by the two halogen bridges, (d) those with three halogen atoms in the meridional-position and two bismuth atoms, which are connected to each other by two sulfur bridges. However, the binuclear bismuth(III) bromide complexes with octahedral geometry reported up to now have cis-sulfur/trans halogen arrangements (Srinivas et al., 2016).

The structures of $\mathbf{1} \mathbf{- 5}$ were determined by single crystal XRD. The selected interatomic distances ( $\AA$ ) and interatomic angles for $\mathbf{1 - 5}$ are reported in Table 1 . The molecular diagrams of 1-5 are shown in Figures 1-5, respectively.

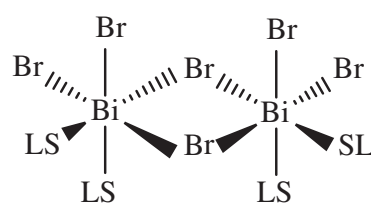

cis-Br/cis-S

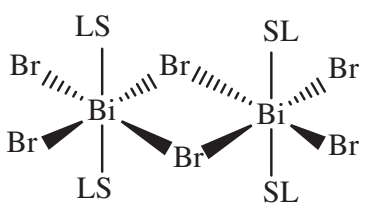

cis-Br/trans-S

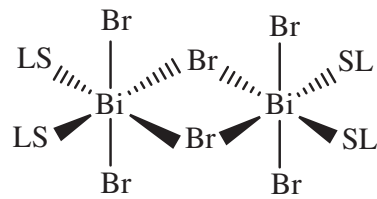

trans-Br/cis-S

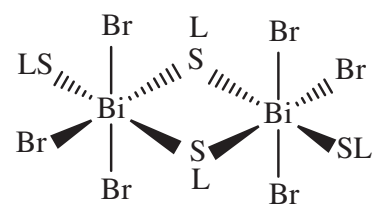

bridging-S
Scheme 3: The possible stereoisomers adopted by bismuth(III) complexes with octahedral geometry.
Complex 1 is crystallized in the orthorhombic space group $\mathrm{Cmc2}_{1}, \mathbf{3}$ and $\mathbf{4}$ in the monoclinic space group $\mathrm{C2} / \mathrm{c}$ and 5 in the triclinic space group $P \overline{1}$. Compounds $\mathbf{1}, \mathbf{3}-\mathbf{5}$ are isostructural, while their structures constitute the first structurally characterized dinuclear bismuth(III) bromide derivatives with a bismuth:ligand ratio of 1:2. The complexes 1, 3-5 are dimeric with a center of inversion in the middle of the $\mathrm{Bi}_{2}(\mu-\mathrm{Br})_{2}$ core in the solid state. The bismuth atoms expose a slightly distorted octahedral geometry. Each bismuth atom is coordinated by two sulfur atoms and four bromine atoms. Two of the bromine atoms are bridging while the other two bromine atoms are bound terminally to bismuth atoms.

The configuration of $\mathbf{1}, \mathbf{3}$ and $\mathbf{4}$ is cis-sulfur/transbromide arrangement, while the corresponding one of $\mathbf{5}$ is trans-sulfur/cis-bromide arrangement (Scheme 3). The crystal structure of 1, 3-5 is further stabilized by hydrogen bonding and weak electrostatic interactions (e.g. S $\cdots \mathrm{Br}$, $\mathrm{S} \cdots \mathrm{S}, \mathrm{C} \cdots \mathrm{C}, \mathrm{C} \cdots \mathrm{H})$. These interactions make up a 3D supramolecular framework.

Complex $\mathbf{2}$ is a mononuclear ionic salt in the solid state and it is crystallized in monoclinic space group $P 2_{1} / c$. To the best of our knowledge, 2 is the first ionic mononuclear octahedral bismuth(III) bromide complex structurally characterized. The ionic compound contains the $\left[\mathrm{BiS}_{4} \mathrm{Br}_{2}\right]^{+}$cation, while a bromide serves as counter anion. The coordination number of bismuth in 2 is six, where the equatorial plane is setup by four sulfur atoms from the thione ligands, while the axial positions are occupied by two bromide ions. A third bromide counter ion neutralizes the complex. The basal interatomic angles in the cation are close to the ideal octahedral values. The neighbouring monomeric octahedral molecules are linked by hydrogen bonding and weak electrostatic interactions (e.g. $\mathrm{Bi} \cdots \mathrm{Br}, \mathrm{Br} \cdots \mathrm{S}, \mathrm{C} \cdots \mathrm{C}$ ). Consequently, these bonding interactions lead to the $3 \mathrm{D}$ supramolecular framework.

The $\mathrm{Bi}-\mathrm{Br}$ interatomic distances in 1-5 vary from 2.684(1) (Bi1-Br3(3)) to 3.117(1) (Bi1-Br1_a (5)) Å. These interatomic distances are in agreement with the corresponding interatomic distances observed in the known bismuth(III) bromide complexes (Li and Li, 2014; Ozturk et al., 2014a,b; Srinivas et al., 2015, 2016). Similarly, the Bi-S interatomic distances vary from 2.707(3) (Bi1-S2A (3)) to 2.966(2) (Bi1-S1 (5)) A in 1-5 The Bi-S interatomic distances are comparable with those found in the known bismuth(III) thione complexes (Li and Li, 2014; Ozturk et al., 2014a,b; Srinivas et al., 2015, 2016; Arda et al., 2016; Yarar et al., 2018). The $C=S$ interatomic distances in 1-5 vary from 1.678(1) (5) to 1.744(1) (4) $\AA$. These bonds are longer than those observed in the free ligands (MMI: $1.681 \AA$ A, MBZIM: $1.684 \AA$ A, tHPMT: $1.722 \AA$, 
Table 1: The selected interatomic distances $(\AA)$ and interatomic angles $\left(^{\circ}\right)$ for the bismuth(III) bromide complexes 1-5.

\begin{tabular}{|c|c|c|c|c|c|c|c|c|c|}
\hline \multicolumn{2}{|l|}{1} & \multicolumn{2}{|l|}{2} & \multicolumn{2}{|l|}{3} & \multicolumn{2}{|l|}{4} & \multicolumn{2}{|l|}{5} \\
\hline \multicolumn{10}{|c|}{ Interatomic distances } \\
\hline Bi1-S2 & $2.758(3)$ & Bi1-S1 & $2.844(3)$ & Bi1-S2A & $2.707(3)$ & $\mathrm{Bi1}-\mathrm{S} 2 \mathrm{~A}$ & $2.716(2)$ & Bi1-S1 & $2.966(2)$ \\
\hline $\mathrm{Bi2}-\mathrm{S} 1$ & $2.710(3)$ & Bi1-S2 & $2.845(3)$ & $\mathrm{Bi1-S2B}$ & $2.721(2)$ & $\mathrm{Bi1}-\mathrm{S} 2 \mathrm{~B}$ & $2.745(4)$ & $\mathrm{Bi} 1-\mathrm{S} 3$ & $2.709(2)$ \\
\hline Bi1-Br3 & $2.937(1)$ & Bi1-Br1 & $2.809(1)$ & Bi1-Br1 & $2.958(1)$ & $\mathrm{Bi1-Br1}$ & $2.718(1)$ & $\mathrm{Bi} 1-\mathrm{Br} 1$ & 2.991(1) \\
\hline $\mathrm{Bi1}-\mathrm{Br} 4$ & $2.725(1)$ & $\mathrm{S} 1-\mathrm{C} 1$ & $1.730(1)$ & $\mathrm{Bi1}-\mathrm{Br} 3$ & $2.698(1)$ & $\mathrm{Bi1}-\mathrm{Br} 3$ & $2.964(1)$ & $\mathrm{Bi} 1-\mathrm{Br} 2$ & $2.761(1)$ \\
\hline Bi1-Br5 & $2.963(1)$ & $\mathrm{S} 2-\mathrm{C} 8$ & $1.722(1)$ & $\mathrm{Bi} 1-\mathrm{Br} 2$ & $3.001(1)$ & $\mathrm{Bi} 1-\mathrm{Br} 2$ & $2.947(1)$ & $\mathrm{Bi1}-\mathrm{Br} 3$ & $2.684(1)$ \\
\hline $\mathrm{Bi} 2-\mathrm{Br} 1$ & $2.851(1)$ & & & Bi1-Br2_a & $3.030(1)$ & Bi1-Br2_a & $3.026(1)$ & Bi1-Br1_a & $3.117(1)$ \\
\hline $\mathrm{Bi} 2-\mathrm{Br} 2$ & $2.749(1)$ & & & $\mathrm{S} 2 \mathrm{~A}-\mathrm{C} 2 \mathrm{~A}$ & $1.736(9)$ & $\mathrm{S} 2 \mathrm{~A}-\mathrm{C} 2 \mathrm{~A}$ & $1.744(1)$ & $\mathrm{S} 1-\mathrm{C} 1$ & $1.678(1)$ \\
\hline $\mathrm{Bi} 2-\mathrm{Br} 5$ & $3.090(1)$ & & & S2B-C $2 B$ & $1.737(1)$ & $\mathrm{S} 2 \mathrm{~B}-\mathrm{C} 2 \mathrm{~B}$ & $1.722(1)$ & $\mathrm{S3}-\mathrm{C} 8$ & $1.711(9)$ \\
\hline $\mathrm{S} 1-\mathrm{C} 1$ & $1.730(1)$ & & & & & & & & \\
\hline $\mathrm{S} 2-\mathrm{C} 5$ & $1.726(1)$ & & & & & & & & \\
\hline \multicolumn{10}{|c|}{ Interatomic angles } \\
\hline $\mathrm{Br} 1-\mathrm{Bi} 2-\mathrm{Br} 2$ & $172.3(5)$ & Br1-Bi1-Br1_a & 180.0 & $\mathrm{Br} 1-\mathrm{Bi} 1-\mathrm{Br} 3$ & $164.2(4)$ & $\mathrm{Br} 1-\mathrm{Bi} 1-\mathrm{Br} 3$ & $168.3(5)$ & $\mathrm{Br} 3-\mathrm{Bi} 1-\mathrm{Br} 1$ & $94.7(3)$ \\
\hline $\mathrm{S} 1-\mathrm{Bi} 2-\mathrm{Br} 5$ & $171.4(6)$ & S1-Bi1-S1_a & 180.0 & S2A-Bi1-Br2_a & $172.7(6)$ & S2A-Bi1-Br2_a & $177.5(1)$ & $\mathrm{Br} 3-\mathrm{Bi} 1-\mathrm{Br} 2$ & $90.6(3)$ \\
\hline $\mathrm{Br} 1-\mathrm{Bi} 2-\mathrm{Br} 5$ & $94.4(4)$ & S2-Bi1-S2_a & 180.0 & $\mathrm{~S} 2 \mathrm{~B}-\mathrm{Bi} 1-\mathrm{Br} 2$ & $174.8(7)$ & S2B-Bi1-Br2_a & $85.3(7)$ & $\mathrm{Br} 2-\mathrm{Bi} 1-\mathrm{Br} 1$ & $171.3(3)$ \\
\hline Br1-Bi2-S1 & $81.9(6)$ & Br1-Bi1-S1 & $86.6(6)$ & $\mathrm{Br} 1-\mathrm{Bi} 1-\mathrm{S} 2 \mathrm{~A}$ & $76.8(6)$ & Br1-Bi1-S2A & $91.6(7)$ & Br3-Bi1-Br1_a & 179.3(3) \\
\hline $\mathrm{Br} 2-\mathrm{Bi} 2-\mathrm{Br} 5$ & $91.4(3)$ & Br1-Bi1-S1_a & $93.3(6)$ & $\mathrm{Br} 1-\mathrm{Bi} 1-\mathrm{S} 2 \mathrm{~B}$ & $74.6(6)$ & $\mathrm{Br} 1-\mathrm{Bi} 1-\mathrm{S} 2 \mathrm{~B}$ & $95.3(7)$ & Br2-Bi1-Br1_a & $89.0(3)$ \\
\hline $\mathrm{Br} 2-\mathrm{Bi} 2-\mathrm{S} 1$ & $92.9(6)$ & Br1-Bi1-S2 & $86.0(6)$ & Br1-Bi1-Br2_a & $99.1(4)$ & $\mathrm{Br} 1-\mathrm{Bi} 1-\mathrm{Br} 2$ & $90.9(5)$ & Br1-Bi1-Br1_a & $85.5(3)$ \\
\hline $\mathrm{Br} 3-\mathrm{Bi1}-\mathrm{Br} 4$ & 171.1(5) & Br1-Bi1-S2_a & $93.9(6)$ & Br1-Bi1-Br2 & $104.0(3)$ & Br1-Bi1-Br2_a & $87.5(4)$ & Bi1-Br1-Bi1_a & $94.4(3)$ \\
\hline S2-Bi1-Br5 & $88.6(6)$ & S1-Bi1-S2 & $90.8(7)$ & $\mathrm{Br3-Bi1-S2A}$ & $95.5(6)$ & Br3-Bi1-S2A & $78.9(7)$ & Br3-Bi1-S3 & $92.6(5)$ \\
\hline $\mathrm{Br} 3-\mathrm{Bi} 1-\mathrm{Br} 5$ & $90.6(3)$ & S1-Bi1-S2_a & $89.1(7)$ & $\mathrm{Br} 3-\mathrm{Bi} 1-\mathrm{S} 2 \mathrm{~B}$ & $93.0(5)$ & $\mathrm{Br} 3-\mathrm{Bi1}-\mathrm{S} 2 \mathrm{~B}$ & $79.2(7)$ & $\mathrm{S} 3-\mathrm{Bi} 1-\mathrm{Br} 2$ & $96.2(5)$ \\
\hline Br3-Bi1-S2 & $82.3(5)$ & & & $\mathrm{Br} 3-\mathrm{Bi} 1-\mathrm{Br} 2$ & $89.1(3)$ & $\mathrm{Br} 3-\mathrm{Bi} 1-\mathrm{Br} 2$ & $95.6(5)$ & $\mathrm{Br3-Bi1-S1}$ & $92.4(5)$ \\
\hline $\mathrm{Br} 4-\mathrm{Bi} 1-\mathrm{Br} 5$ & $95.8(3)$ & & & Br3-Bi1-Br2_a & $89.7(4)$ & Br3-Bi1-Br2_a & $102.1(4)$ & S3-Bi1-S1 & $167.1(6)$ \\
\hline \multirow[t]{3}{*}{ Br4-Bi1-S2_a } & $91.8(5)$ & & & S2A-Bi1-S2B & $97.6(9)$ & S2A-Bi1-S2B & $97.0(1)$ & $\mathrm{Br} 2-\mathrm{Bi1}-\mathrm{S} 1$ & $95.4(5)$ \\
\hline & & & & Br2-Bi1-Br2_a & $88.3(4)$ & Br2-Bi1-Br2_a & $88.6(5)$ & S3-Bi1-Br1 & $76.8(5)$ \\
\hline & & & & Bi1-Br2-Bi1_a & $91.6(4)$ & Bi1-Br2-Bi1_a & $91.3(5)$ & $\mathrm{S} 1-\mathrm{Bi} 1-\mathrm{Br} 1$ & $91.0(5)$ \\
\hline
\end{tabular}

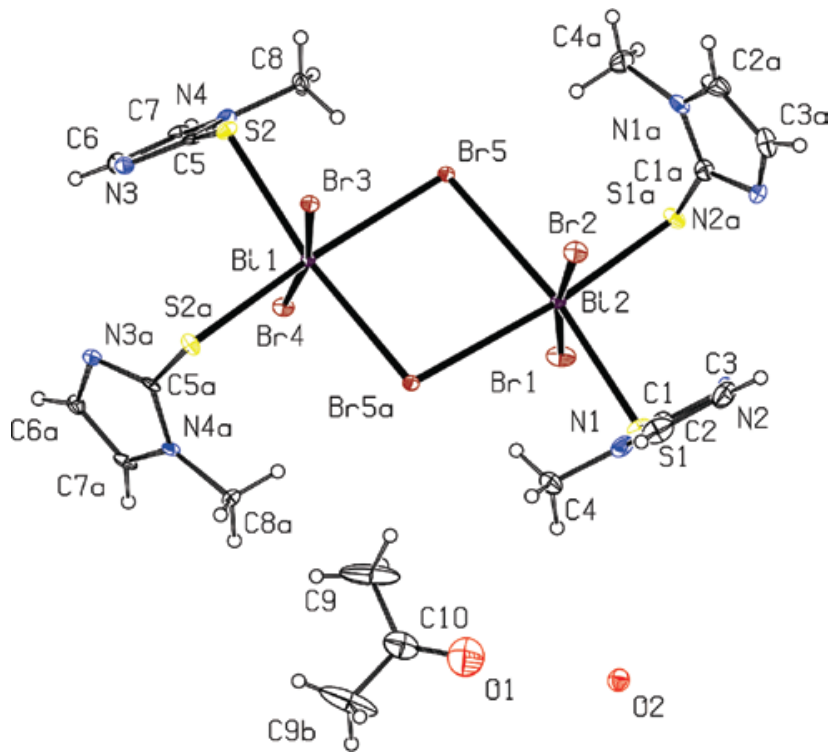

Figure 1: The molecular diagram of $\left\{\left[\mathrm{BiBr}_{2}\left(\mu_{2}-\mathrm{Br}\right)\right.\right.$ $\left.\left.(\mathrm{MMI})_{2}\right]_{2} \cdot \mathrm{CH}_{3} \mathrm{COCH}_{3} \cdot \mathrm{H}_{2} \mathrm{O}\right\}$ (1).

PYT: $1.692 \AA$ and MBZT: $1.668 \AA$ ) (Ohms et al., 1982; Ravikuma et al., 1995; Popović et al., 2001; Lodochnikova et al., 2013). They are, however, in the range of those measured in other

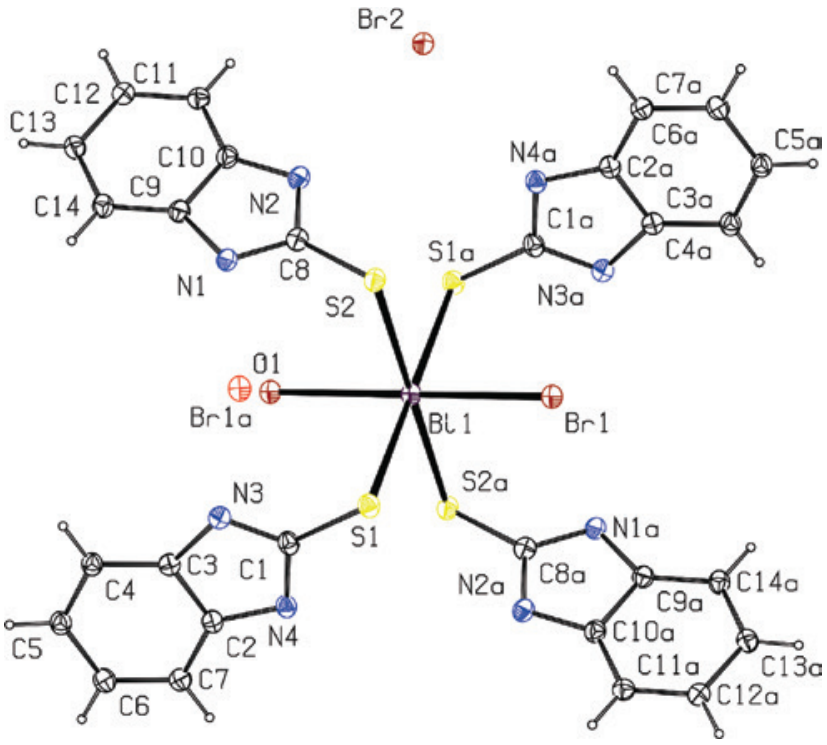

Figure 2: The molecular diagram of $\left\{\left[\mathrm{BiBr}_{2}(\mathrm{MBZIM})_{4}\right] \cdot \mathrm{Br} \cdot 2 \mathrm{H}_{2} \mathrm{O}\right\}$ (2).

antimony(III) halide compounds (Ozturk et al., 2007, 2009, 2010). The $C=S$ interatomic distance of the ligands suggests their coordination through their thionate forms. 


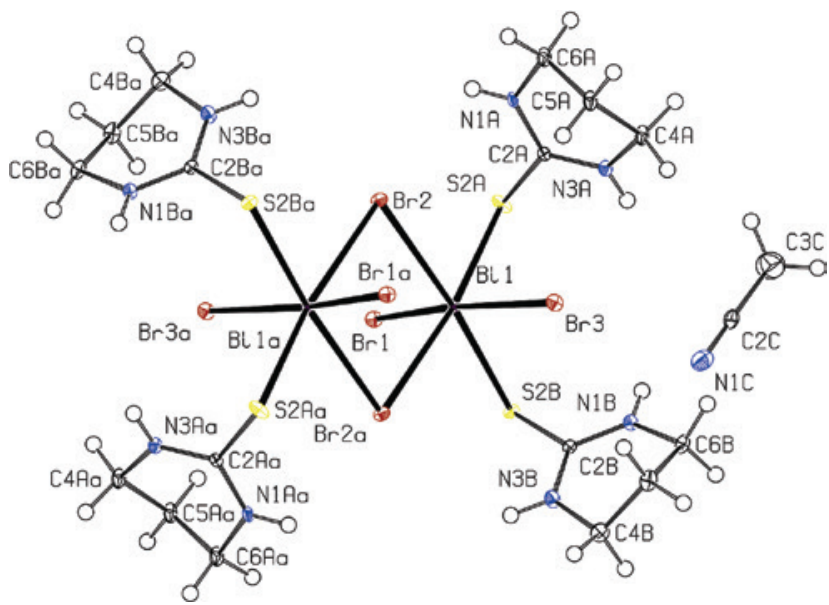

Figure 3: The molecular diagram of $\left\{\left[\mathrm{BiBr}_{2}\left(\mu_{2}-\mathrm{Br}\right)(\mathrm{tHPMT})_{2}\right]_{2} \cdot \mathrm{CH}_{3} \mathrm{CN}\right\}$ (3).

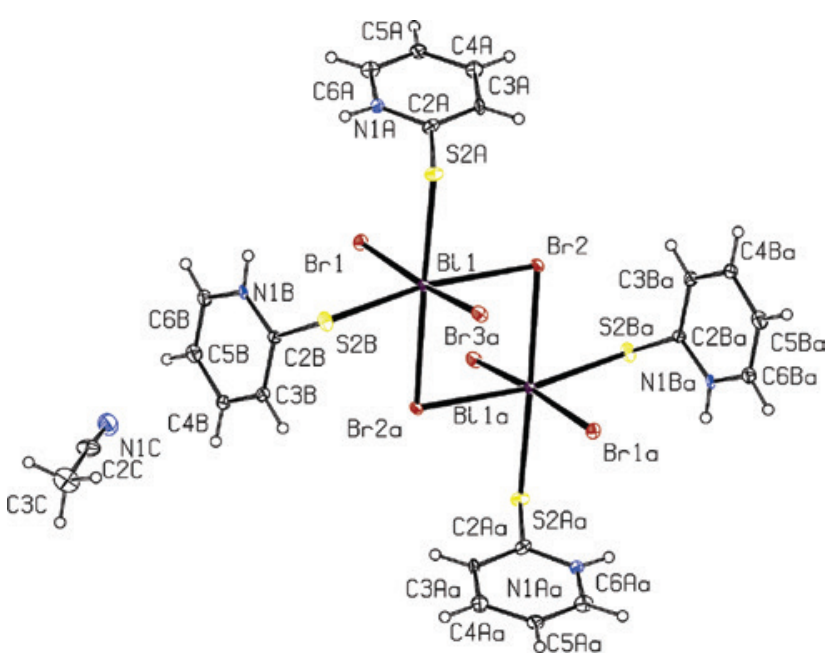

Figure 4: The molecular diagram of $\left\{\left[\mathrm{BiBr}_{2}\left(\mu_{2}-\mathrm{Br}\right)(\mathrm{PYT})_{2}\right]_{2} \cdot \mathrm{CH}_{3} \mathrm{CN}\right\}$ (4).

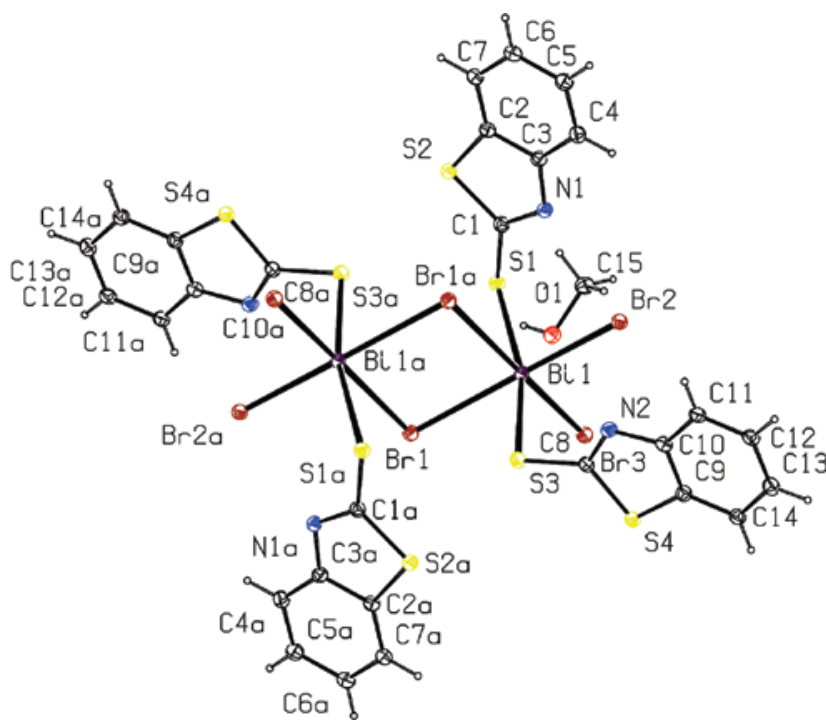

Figure 5: The molecular diagram of $\left\{\left[\mathrm{BiBr}_{2}\left(\mu_{2}-\mathrm{Br}\right)(\mathrm{MBZT})_{2}\right]_{2} 2 \mathrm{CH}_{3} \mathrm{OH}\right\}$ (5).

\section{Biological studies}

The in vitro antiproliferative activities of 1-5 were tested against the human adenocarcinoma breast (MCF-7) and cervix (HeLa) cells by SRB assay after their incubation for $48 \mathrm{hrs}$.

Compounds 1-5, exhibit moderate activity against the adenocarcinoma cells. The $\mathrm{IC}_{50}$ values of $\mathbf{4}$ against HeLa and MCF-7 cells are $6.5 \pm 0.7 \mu \mathrm{M}$ and $9.7 \pm 1.0 \mu \mathrm{M}$ respectively (Table 2). Therefore, the coordination of PYT enhances its biological activity. On the contrary, this is not observed when the rest of the ligands were used. Similarly, when bismuth(III) chloride complexes of the same thioamides (Yarar et al., 2018) were tested against the same cell lines, the corresponding one of the PYT exhibits the stronger activity once again. Among the bismuth(III) halide compounds of the thioamides tested (Table 2) against the HeLa and MCF-7 cells, a stronger activity is observed for the $\left\{\left[\mathrm{BiCl}_{3}\left(\mu_{2}-\mathrm{S} \text {-PYT }\right)(\mathrm{PYT})\right]_{2}\right\}$. A stronger activity of $\mathbf{4 - 5}$ has also been detected against HeLa than MCF-7 cells. The IC $\mathrm{I}_{50}$ values of 5 are $15.0 \pm 1.1 \mu \mathrm{M}$ and $>30 \mu \mathrm{M}$, against the HeLa and MCF-7 cells, respectively. However, the cisplatin exhibits higher activity against the HeLa and MCF-7 cells than the study compounds $\mathbf{1 - 5}$. The $\mathrm{IC}_{50}$ values of the ligands are higher than $30 \mu \mu$ against the MCF-7 and HeLa cells.

The toxicities of 1-5 were studied against the non-cancerous cells MRC-5. The $\mathrm{IC}_{50}$ values of $\mathbf{1 - 3 , 5}$ are higher than $30 \mu \mathrm{M}$, indicating non = toxic behavior. However, the $\mathrm{IC}_{50}$ value of 4 against MRC- 5 is $7.1 \pm 0.6 \mu \mathrm{M}$, which is close to the corresponding one found against the HeLa and MCF-7 cells (6.5 \pm 0.7 and $9.7 \pm 1.0 \mu \mathrm{M}$, respectively) (Table 2).

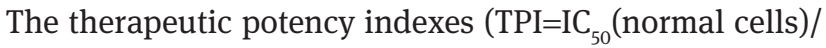
$\mathrm{IC}_{50}$ (tumor cells) of $\mathbf{4}$ are 1.1 and 0.7 for the HeLa and MCF-7 cells respectively. In addition, 1-5 exhibit lower toxicity than cisplatin $\left(\mathrm{IC}_{50}=1.1 \pm 0.2 \mu \mathrm{M}\right)$. The $\mathrm{IC}_{50}$ values of the ligands against the MRC- 5 cells are higher than $30 \mu \mathrm{M}$.

In comparison, the bismuth(III)- dithiocarbamate complexes exhibit a significantly higher activity against both the HeLa and MCF-7 cells (Table 2). Their $\mathrm{IC}_{50}$ values lie between 0.023 and $0.33 \mu \mathrm{M}$ (Yarar et al., 2018).

\section{Study of the peroxidation of the linoleic acid by the enzyme lipoxygenase in the presence of bismuth(III) bromide complexes 1-5 and free thiomide ligands}

LOXs are a group of oxidative enzymes with a non-heme iron atom in their active site (Haining and Axelrod, 1958; Knapp and Klinman, 2003); they are often associated with tumor cell proliferation, differentiation and 
Table 2: The IC ${ }_{50}$ values for cell viability found for the bismuth(III) complexes against the human adenocarcinoma cells HeLa (cervix), MCF-7 (breast) and MRC- 5 cells (normal human fetal lung fibroblast cells).

\begin{tabular}{|c|c|c|c|c|c|}
\hline \multirow[t]{2}{*}{ Compounds } & \multirow[b]{2}{*}{$\operatorname{LOX}(\mu \mathrm{M})$} & \multirow[b]{2}{*}{ HeLa } & \multicolumn{2}{|c|}{$\mathrm{IC}_{50}$ values $(\mu \mathrm{M})$} & \multirow[t]{2}{*}{ Reference } \\
\hline & & & MCF-7 & MRC-5 & \\
\hline$\left\{\left[\mathrm{BiBr}{ }_{2}\left(\mu_{2}-\mathrm{Br}\right)(\mathrm{MMI})_{2}\right]_{2} \cdot \mathrm{CH}_{3} \mathrm{COCH}_{3} \cdot \mathrm{H}_{2} \mathrm{O}\right\}$ (1) & 66.7 & $>30$ & $>30$ & $>30$ & a \\
\hline$\left\{\left[\mathrm{BiBr}_{2}(\mathrm{MBZIM})_{4}\right] \cdot \mathrm{Br} \cdot 2 \mathrm{H}_{2} \mathrm{O}\right\}(2)$ & 48.8 & $>30$ & $>30$ & $>30$ & a \\
\hline$\left\{\left[\mathrm{BiBr}_{2}\left(\mu_{2}-\mathrm{Br}\right)(\mathrm{tHPMT})_{2}\right]_{2} \cdot \mathrm{CH}_{3} \mathrm{CN}\right\}$ (3) & 65.3 & $>30$ & $>30$ & $>30$ & a \\
\hline$\left\{\left[\mathrm{BiBr}_{2}\left(\mu_{2}-\mathrm{Br}\right)(\mathrm{PYT})_{2}\right]_{2} \cdot \mathrm{CH}_{3} \mathrm{CN}\right\}(4)$ & 176.8 & $6.5 \pm 0.7$ & $9.7 \pm 1.0$ & $7.1 \pm 0.6$ & a \\
\hline$\left\{\left[\mathrm{BiBr}{ }_{2}\left(\mu_{2}-\mathrm{Br}\right)(\mathrm{MBZT})_{2}\right]_{2} 2 \mathrm{CH}_{3} \mathrm{OH}\right\}(5)$ & 48.6 & $15.0 \pm 1.1$ & $>30$ & $>30$ & a \\
\hline$\left\{\left[\mathrm{BiCl}_{2}\left(\mu_{2}-\mathrm{Cl}\right)(\mathrm{MMI})_{2}\right]_{2} \cdot\left(\mathrm{CH}_{3}\right)_{2} \mathrm{CO}\right\}$ & 68.2 & $>30$ & $>30$ & $11.2 \pm 1.0$ & (Yarar et al., 2018) \\
\hline$\left\{\left(\left[\mathrm{BiCl}_{2}(\mathrm{MBZIM})_{4}\right]^{+}\right) \cdot 2\left(\mathrm{Cl}^{-}\right) \cdot\left(\mathrm{H}_{3} \mathrm{O}^{+}\right) \cdot 2 \mathrm{H}_{2} \mathrm{O}\right\}$ & 57.0 & $>30$ & 13.6 & $>30$ & (Yarar et al., 2018) \\
\hline$\left[\mathrm{BiCl}_{3}(\mathrm{tHPMT})_{3}\right]$ & 67.2 & $>30$ & $>30$ & $>30$ & (Yarar et al., 2018) \\
\hline$\left\{\left[\mathrm{BiCl}_{3}\left(\mu_{2}-\mathrm{S}-\mathrm{PYT}\right)(\mathrm{PYT})\right]_{2}\right\}$ & 169.5 & $6.1 \pm 0.2$ & $6.1 \pm 0.2$ & $4.7 \pm 0.1$ & (Yarar et al., 2018) \\
\hline$\left.\left[\mathrm{BiCl}_{3}(\mathrm{MBZT})_{2}\right] \mathrm{H}_{2} \mathrm{O}\right\}$ & 57.0 & $>30$ & $>30$ & $>30$ & (Yarar et al., 2018) \\
\hline $\mathrm{MMI}$ & 377 & $>30$ & $>30$ & $>30$ & (Yarar et al., 2018) \\
\hline MBZIM & 286 & $>30$ & $>30$ & $>30$ & a \\
\hline tHPMT & 286 & $>30$ & $>30$ & $>30$ & (Yarar et al., 2018) \\
\hline PYT & 1796 & $>30$ & $>30$ & $>30$ & (Yarar et al., 2018) \\
\hline MBZT & 188.3 & $>30$ & $>30$ & $>30$ & (Yarar et al., 2018) \\
\hline$\left\{\left[\mathrm{BiBr}\left(\mathrm{Me}_{2} \mathrm{DTC}\right)_{2}\right]\right\}_{\mathrm{n}}$ & & $0.2 \pm 0.01$ & $0.08 \pm 0.01$ & $0.25 \pm 0.01$ & (Arda et al., 2016) \\
\hline$\left\{\left[\mathrm{BiBr}_{2}\left(\mathrm{Et}_{2} \mathrm{DTC}\right)\right]\right\}_{\mathrm{n}}$ & & $0.2 \pm 0.01$ & $0.08 \pm 0.006$ & $0.32 \pm 0.02$ & (Arda et al., 2016) \\
\hline$\left\{\left[\mathrm{Bil}_{2}\left(\mathrm{Me}_{2} \mathrm{DTC}\right)\right]\right\}_{\mathrm{n}}$ & & $0.3 \pm 0.02$ & $0.1 \pm 0.003$ & $0.29 \pm 0.01$ & (Arda et al., 2016) \\
\hline$\left\{\left[\mathrm{Bil}\left(\mathrm{Et}_{2} \mathrm{DTC}\right)_{2}\right]\right\}_{\mathrm{n}}$ & & $0.1 \pm 0.01$ & $0.05 \pm 0.002$ & $0.18 \pm 0.01$ & (Arda et al., 2016) \\
\hline$\left\{\left[\mathrm{Bil}\left(\mu_{2}-\mathrm{I}\right)\left(\mathrm{Et}_{2} \mathrm{DTC}\right)_{2}\right]_{2}\right\}_{\mathrm{n}}$ & & $0.05 \pm 0.006$ & $0.07 \pm 0.008$ & $0.15 \pm 0.02$ & (Arda et al., 2016) \\
\hline$\left\{\left[\mathrm{BiCl}\left(\mathrm{Me}_{2} \mathrm{DTC}\right)_{2}\right]_{n}\right\}$ & & $0.33 \pm 0.03$ & $0.023 \pm 0.003$ & - & (Ozturk et al., 2017) \\
\hline$\left\{\left[\mathrm{Bi}\left(\mathrm{Et}_{2} \mathrm{DTC}\right)_{3}\right]_{2}\right\}$ & & $0.19 \pm 0.02$ & $0.043 \pm 0.008$ & - & (Ozturk et al., 2017) \\
\hline cisplatin & & $3.9 \pm 0.1$ & $5.5 \pm 0.4$ & $1.1 \pm 0.2$ & (Yarar et al., 2018) \\
\hline
\end{tabular}

${ }^{\mathrm{a}}$ This work. $\mathrm{Me}_{2} \mathrm{DTCH}$, Dimethyldithiocarbamate; $\mathrm{Et}_{2} \mathrm{DTCH}$, diethyldithiocarbamate.

apoptosis (Samuelsson et al., 1987). Some evidence have proven the crucial role of LOX in cancer (Poyraz et al., 2011; Banti et al., 2016) as its inhibition induces apoptosis (Banti et al., 2016). The degree of LOX activity (A, \%) in the presence of 1-5 was calculated according to the method described previously (Xanthopoulou et al., 2008; Ozturk et al., 2010; Poyraz et al., 2011). The effects of 1-5 and free thioamide ligands upon the oxidation of linoleic acid by the enzyme LOX were studied in a wide concentration range (Figure 6). The $\mathrm{IC}_{50}$ values of $\mathbf{1 - 5}$ are $66.73(\mathbf{1}), 48.83$ (2), 65.27 (3), 176.80 (4) and $48.58 \mu \mathrm{M}$ (5), and for their free ligands, 377 (MMI), 286 (MBZIM), 219 (tHPMT), 1796 (PYT) and $188.3 \mu \mathrm{M}$ (MBZT), respectively (Figure 7). The Bi(III) complexes 1-5 inhibit LOX activity in a moderate manner, which is in agreement with the antiproliferative studies as the compounds possess low cytotoxic activity. The $\mathrm{IC}_{50}$ values of bromide bismuth(III) complexes against LOX are in accordance with the corresponding ones of their chloride analogues (Figure 7). Although 1-5 exhibit inhibitory activity against LOX; however, this is lower than the corresponding one of the organotin(IV) or silver(I) complexes (Xanthopoulou et al., 2008; Banti et al., 2016). This activity follows the relatively low cytotoxicity of these complexes.

\section{Conclusions}

In conclusion, five novel bismuth(III) bromide complexes with heterocyclic thioamide ligands have been successfully synthesized and characterized. The complexes of formulae $\left\{\left[\mathrm{BiBr}_{2}\left(\mu_{2}-\mathrm{Br}\right)(\mathrm{MMI})_{2}\right]_{2} \cdot \mathrm{CH}_{3} \mathrm{COCH}_{3} \cdot \mathrm{H}_{2} \mathrm{O}\right\}$ (1), $\quad\left\{\left[\mathrm{BiBr}_{2}(\mathrm{MBZIM})_{4}\right] \cdot \mathrm{Br} \cdot 2 \mathrm{H}_{2} \mathrm{O}\right\} \quad$ (2), $\quad\left\{\left[\mathrm{BiBr}_{2}\left(\mu_{2}-\mathrm{Br}\right)\right.\right.$ $\left.\left.(\text { tHPMT })_{2}\right]_{2} \cdot \mathrm{CH}_{3} \mathrm{CN}\right\}(\mathbf{3}),\left\{\left[\mathrm{BiBr}_{2}\left(\mu_{2}-\mathrm{Br}\right)(\mathrm{PYT})_{2}\right]_{2} \cdot \mathrm{CH}_{3} \mathrm{CN}\right\}(\mathbf{4})$ and $\left\{\left[\mathrm{BiBr}_{2}\left(\mu_{2}-\mathrm{Br}\right)(\mathrm{MBZT})_{2}\right]_{2} \cdot 2 \mathrm{CH}_{3} \mathrm{OH}\right\}$ (5) show versatile coordination modes. The molecular structures of complexes 1, 3, 4 and 5 are isostructural. These are the first examples of dinuclear bismuth(III) bromide compounds that have been structurally characterized with square pyramidal (SP) conformation around the metal center. The secondary $\mathrm{Bi} \cdots\left(\mu_{2}-\mathrm{Br}\right)$ bonding interactions developed in 1, 3, 4 and 5 lead to octahedral arrangement $(\mathrm{Oh})$. Moreover, the molecular structure of compound $\mathbf{2}$ is unique as it is the first ionic mononuclear octahedral bismuth(III) bromide complex.

Furthermore, the in vitro antiproliferative activity of 1-5 was tested against human adenocarcinoma breast (MCF-7) and cervix (HeLa) cells. Between the bromide compounds tested here, $\left\{\left[\mathrm{BiBr}_{2}\left(\mu_{2}-\mathrm{Br}\right)(\mathrm{PYT})_{2}\right]_{2} \cdot \mathrm{CH}_{3} \mathrm{CN}\right\}$ (4) exhibits the 

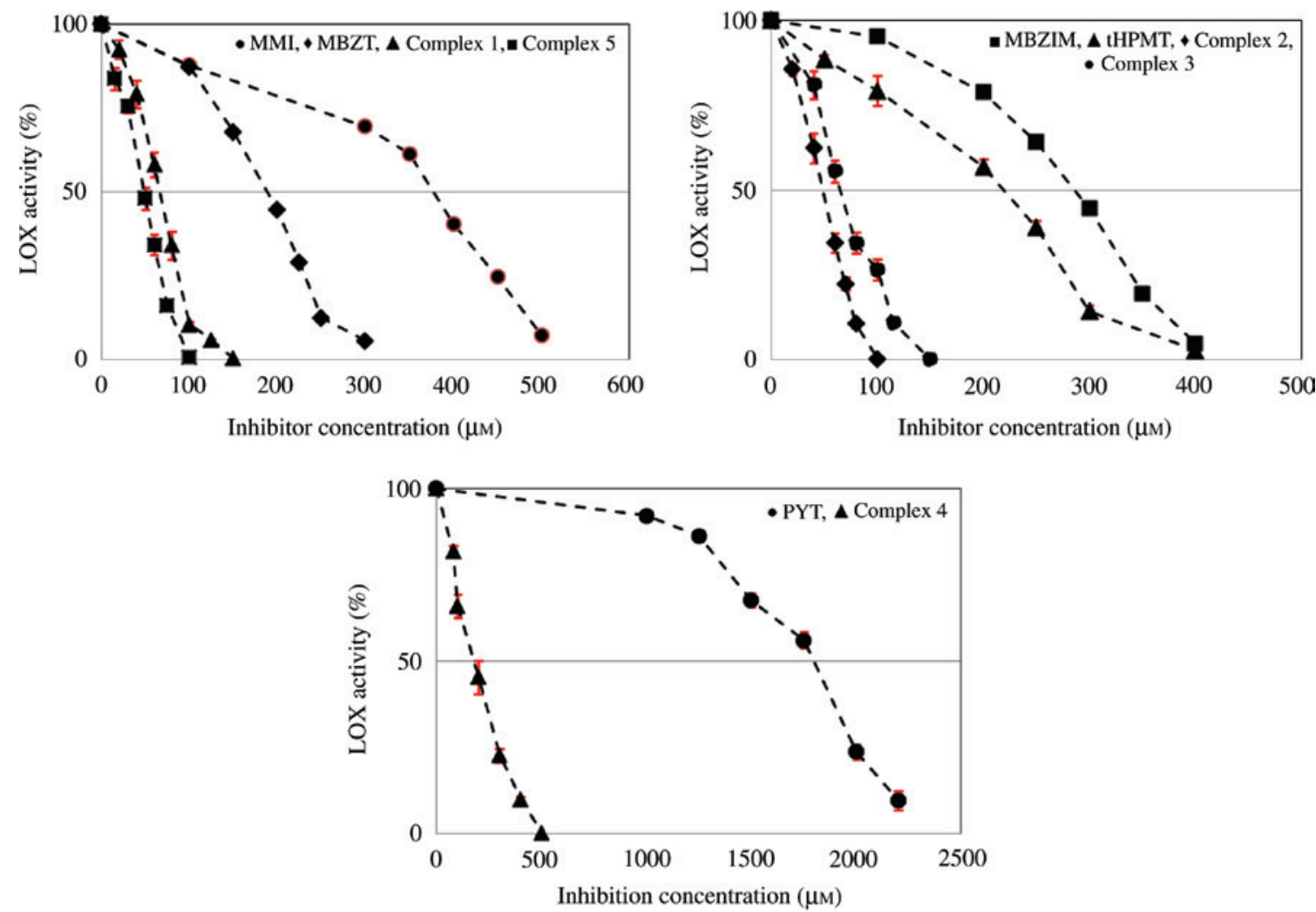

Figure 6: The inhibitory effects of 1-5 and thioamide ligands against LOX in various concentrations.

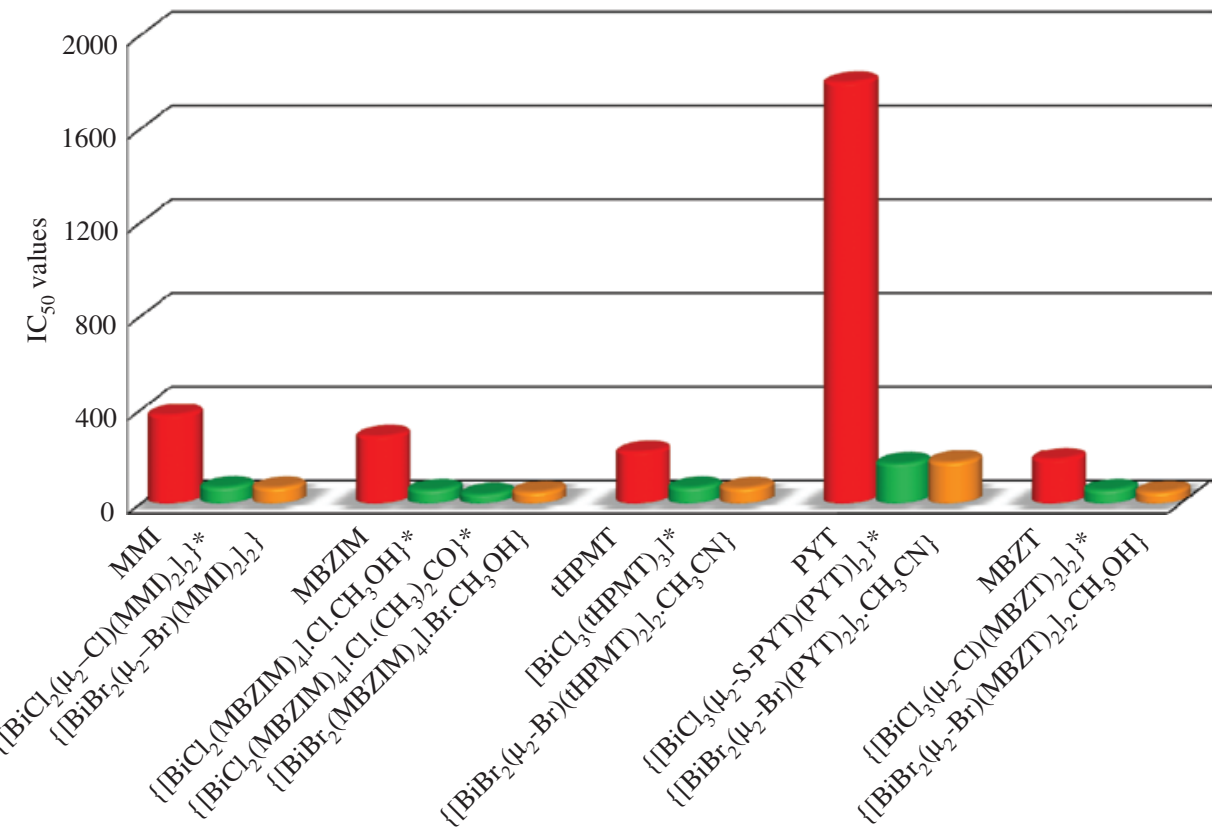

Figure 7: The $\mathrm{IC}_{50}$ values of the free thioamide ligands and bismuth(III) bromide and chloride against LOX.

lower $\mathrm{IC}_{50}$ values (stronger activity) against cells, which is comparable to the corresponding chloride ones (Table 2). Among the bismuth bromides and chloride complexes, those of 2-mercapto-pyridine 4 and $\left\{\left[\mathrm{BiCl}_{3}\left(\mu_{2}-\mathrm{S} \text {-PYT)(PYT }\right]_{2}\right\}\right.$ exhibit the strongest such activity (Table 2). Therefore, PYT enhances the biological activity, although the formation of octahedral arrangement around the metal centers is formed either by $\mu_{2}$-Br or $\mu_{2}$-S-PYT secondary binding interactions. 
Furthermore, bismuth(III) compounds with dithiocarbamates exhibit significantly higher activity than those of heterocyclic thioamides, which in case of $\left\{\left[\mathrm{BiCl}\left(\mathrm{Me}_{2} \mathrm{DTC}\right)_{2}\right]_{n}\right\}$, increase even up to 250-fold than the corresponding one of cisplatin (Table 2). The inhibitory activity of the bromides or chloride bismuth(III) compounds against LOX follows their corresponding antiproliferative behaviour, thus confirming our assumption that this inhibition might be used as an indicator for the antiproliferative potential of a formulation (Xanthopoulou et al., 2008; Poyraz et al., 2011; Banti et al., 2016). In conclusion, based on the cell antiproliferative studies presented here, more efficient Bi(III) metallodrugs should be designed in the future within the class of dithiocarbamate ligands.

\section{Experimental}

\section{Materials and instruments}

All solvents used were of reagent grade. Bismuth(III) bromide (Merck, Darmstadt, Germany) and the 2-mercapto-1-methyl-imidazolidine (Sigma), 2-mercapto-benzimidazole (Merck, Darmstadt, Germany), 2-mercapto-3,4,5,6-tetrahydro-pyrimidine (Merck Darmstadt, Germany), 2-mercapto-pyridine (Merck, Darmstadt, Germany) and 2-mercapto-benzothiazole (Merck, Darmstadt, Germany) were used without further purification. The elemental analyses for $\mathrm{C}, \mathrm{H}, \mathrm{N}$, and S were carried out with a Carlo Erba EA MODEL 1108 elemental analyzer (Milan, Italy). The melting points were measured in open tubes with a STUART SMP30 (Stone, Staffordshire, UK) scientific apparatus and were left uncorrected. The FT-IR spectra were recorded in the 4000-400 $\mathrm{cm}^{-1}$ region with Bruker Optics, Vertex 70 FT-IR spectrometer (Ettlingen, Germany) using ATR techniques. The far IR absorption spectra were recorded in $400-50 \mathrm{~cm}^{-1}$ using the FT-IR Bruker Equinox 55 spectrometer equipped with a Bruker Hyperion 1000 microscope (Ettlingen, Germany). Micro Raman spectra (64 scans) were recorded at room temperature using a low-power $(\sim 30 \mathrm{~mW})$ green $(514.5) \mathrm{mm}$ laser on a Renishaw In Via spectrometer set at 2.0 resolution. The ${ }^{1} \mathrm{H}$ and ${ }^{13} \mathrm{C}$ NMR spectra were recorded with a Varian Unity Inova $500 \mathrm{MHz}$ spectrometer (Palo Alto, CA, USA) in DMSO- $d_{6}$ with chemical shifts given in parts per million referenced to internal TMS (H). The molar conductivity of complexes in DMSO was measured by means of a VWR Phenomenal conductometer CO $3000 \mathrm{~L}$ (UK). The TG-DTA was carried out on a Seiko SII TG/DTA 7200 (Tokyo, Japan) apparatus under $\mathrm{N}_{2}$ flow $\left(50 \mathrm{~cm}^{3} \mathrm{~min}^{-1}\right)$ with a heating rate of $10^{\circ} \mathrm{C} \mathrm{min}^{-1}$. The UV spectra were recorded in a Shimadzu UV-2600 UVVis spectrophotometer (Kyoto, Japan).

\section{Synthesis and crystallization of the compounds}

The $\left\{\left[\mathrm{BiBr}_{2}\left(\mu_{2}-\mathrm{Br}\right)(\mathrm{MMI})_{2}\right]_{2} \cdot \mathrm{CH}_{3} \mathrm{COCH}_{3} \cdot \mathrm{H}_{2} \mathrm{O}\right\} \quad$ (1): $\quad 0.25 \quad \mathrm{mmol}$ bismuth(III) bromide $(0.112 \mathrm{~g})$ and $0.50 \mathrm{mmol}$ 2-mercapto-1-methylimidazole $(0.057 \mathrm{~g})$ were dissolved in $10 \mathrm{~mL}$ acetone, respectively. The resulting solution was stirred at room temperature for $4 \mathrm{~h}$. The obtained solution was filtered. The clear orange solution was kept in darkness at room temperature. One week later, orange crystals suitable for single crystal XRD data were obtained.

1: Orange crystals; yield $85 \%$; melting point: $118-120^{\circ} \mathrm{C}$; $\mathrm{Mw}=1430.10 \mathrm{~g} / \mathrm{mol}$. Elemental analysis: found $\mathrm{C}=14.22 ; \mathrm{H}=1.73$; $\mathrm{N}=8.17 ; \mathrm{S}=9.41 \%$, calculated (without solvent molecules) for $\mathrm{C}_{16} \mathrm{H}_{24} \mathrm{Bi}_{2} \mathrm{Br}_{6} \mathrm{~N}_{8} \mathrm{~S}_{4}: \mathrm{C}=14.19 ; \mathrm{H}=1.78 ; \mathrm{N}=8.28 ; \mathrm{S}=9.47 \%$. Mid-IR $\left(\mathrm{cm}^{-1}\right)$ : 3130 w, 1701 w, 1689 w, 1570 s, 1508 w, 1468 m, 1443 m, 1408 w, 1354 m, 1284 m, 1229 w, 1157 s, 1088 m, 1020 w, 920 m, 878 w, 779 w, 743 s, 669 s, 609 w, 527 w, 511 m, 473 w, 405 w. Soluble in acetonitrile, acetone, tetrahydrofuran, dimethylsulfoxide. UV-Vis (DMSO): $\lambda_{\text {max }}$ $(\log \varepsilon)=266$ (4.87) and 304 (4.05). $\Lambda_{\mathrm{M}}$ (DMSO): $23.6 \Omega^{-1} \mathrm{~cm}^{2} \mathrm{~mol}^{-1}$.

$\left\{\left[\mathrm{BiBr}_{2}(\mathrm{MBZIM})_{4}\right] \cdot \mathrm{Br} \cdot 2 \mathrm{H}_{2} \mathrm{O}\right\}$ (2): A solution of bismuth(III) bromide $(0.112 \mathrm{~g}, 0.25 \mathrm{mmol})$ in acetonitrile $\left(10 \mathrm{~cm}^{3}\right)$ was added to the solution of 2-mercaptobenzimidazole $(0.077 \mathrm{~g}, 0.50 \mathrm{mmol})$ in methanol $\left(10 \mathrm{~cm}^{3}\right)$. The resulting yellow solution was stirred at room temperature for $3 \mathrm{~h}$. The obtained solution was filtered. The clear yellow solution was kept in darkness at room temperature. Two weeks later, red crystals suitable for single crystal XRD data were obtained.

2: Red crystals; yield $89 \%$; melting point: $228-231^{\circ} \mathrm{C}$; $\mathrm{Mw}=1085.48 \mathrm{~g} / \mathrm{mol}$. Elemental analysis: found $\mathrm{C}=32.09 ; \mathrm{H}=2.27$; $\mathrm{N}=10.57 ; \mathrm{S}=12.09 \%$; calculated (without solvent molecules) for $\mathrm{C}_{28} \mathrm{H}_{24} \mathrm{BiBr}_{3} \mathrm{~N}_{8} \mathrm{~S}_{4}: \mathrm{C}=32.05 ; \mathrm{H}=2.30 ; \mathrm{N}=10.68 ; \mathrm{S}=12.22 \%$. Mid-IR $\left(\mathrm{cm}^{-1}\right)$ : $3544 \mathrm{w}, 3068 \mathrm{w}, 1616 \mathrm{w}, 1591 \mathrm{~m}, 1541 \mathrm{w}, 1491 \mathrm{~s}, 1148 \mathrm{~s}, 1389 \mathrm{w}$, 1346 s, 1254 w, 1219 w, 1169 m, 1148 w, 1111 w, 1005 m, 972 m, 856 w, $814 \mathrm{w}, 752 \mathrm{~s}, 741 \mathrm{~s}, 619 \mathrm{w}, 598 \mathrm{~s}, 467 \mathrm{~m}, 413 \mathrm{~m}$. UV-Vis (DMSO): $\lambda_{\max }$ $(\log \varepsilon)=250.5$ (4.68), 312.5 (5.14). Soluble in methanol, ethanol, acetonitrile, acetone, tetrahydrofuran, dimethylsulfoxide. $\Lambda_{\mathrm{M}}$ (DMSO): $13.9 \Omega^{-1} \mathrm{~cm}^{2} \mathrm{~mol}^{-1}$.

$\left\{\left[\mathrm{BiBr}_{2}\left(\mu_{2}-\mathrm{Br}\right)(\mathrm{tHPMT})_{2}\right]_{2} \cdot \mathrm{CH}_{3} \mathrm{CN}\right\}$ (3): A solution of 2-mercapto3,4,5,6-tetrahydro-pyrimidine $(0.058 \mathrm{~g}, 0.50 \mathrm{mmol})$ in methanol $\left(10 \mathrm{~cm}^{3}\right)$ was added to a solution of bismuth(III) bromide $(0.112 \mathrm{~g}$, $0.25 \mathrm{mmol})$ in acetonitirile $\left(10 \mathrm{~cm}^{3}\right)$. The resulting yellow solution was stirred at room temperature for $30 \mathrm{~min}$. The obtained solution was filtered. The clear yellow solution was kept in darkness at room temperature. One-week later, yellow crystals suitable for single crystal XRD data were obtained.

3: Yellow crystals; yield $86 \%$; melting point: $113-116^{\circ} \mathrm{C}$; $\mathrm{Mw}=1403.18 \mathrm{~g} / \mathrm{mol}$. Elemental analysis: found $\mathrm{C}=15.38 ; \mathrm{H}=2.47$; $\mathrm{N}=9.05 ; \mathrm{S}=9.09 \%$ calculated for $\mathrm{C}_{18} \mathrm{H}_{35} \mathrm{Bi}_{2} \mathrm{Br}_{6} \mathrm{~N}_{9} \mathrm{~S}_{4}: \mathrm{C}=15.41 ; \mathrm{H}=2.51$; $\mathrm{N}=8.98 ; \mathrm{S}=9.14 \%$. Mid-IR $\left(\mathrm{cm}^{-1}\right): 3342 \mathrm{w}, 3265 \mathrm{~m}, 1595 \mathrm{~s}, 1539 \mathrm{~s}$, 1421 w, 1410 m, 1360 m, 1315 m, 1203 s, 1111 w, 1067 w, 972 w, 937 w, 876 w, 808 m, 687 m, 623 m, 563 m, 540 m, 517 m, 410 m. UV-Vis (DMSO): $\lambda_{\max }(\log \varepsilon)=257$ (4.83) and 298 (4.09). Soluble in acetonitrile, acetone, tetrahydrofuran, dimethylsulfoxide. $\Lambda_{\mathrm{M}}$ (DMSO):18.8 $\Omega^{-1} \mathrm{~cm}^{2} \mathrm{~mol}^{-1}$.

$\left\{\left[\mathrm{BiBr}_{2}\left(\mu_{2}-\mathrm{Br}\right)(\mathrm{PYT})_{2}\right]_{2} \cdot \mathrm{CH}_{3} \mathrm{CN}\right\}$ (4): A solution of 2-mercaptopyridine $(0.055 \mathrm{~g}, 0.50 \mathrm{mmol})$ in methanol $\left(10 \mathrm{~cm}^{3}\right)$ was added to a solution of bismuth(III) bromide (0.112 g, $0.25 \mathrm{mmol})$ in acetonitrile $\left(10 \mathrm{~cm}^{3}\right)$. The resulting yellow solution was stirred at room temperature for $30 \mathrm{~min}$. The obtained solution was filtered. The clear orange solution was kept in darkness at room temperature. Two weeks later, yellow crystals suitable for single crystal XRD data were obtained.

4: Yellow crystals; yield $89 \%$; melting point: $118-120^{\circ} \mathrm{C}$; $\mathrm{Mw}=1383.10 \mathrm{~g} / \mathrm{mol}$. Elemental analysis: found $\mathrm{C}=19.18 ; \mathrm{H}=1.71$; $\mathrm{N}=5.13 ; \mathrm{S}=9.32 \%$; calculated for $\mathrm{C}_{22} \mathrm{H}_{23} \mathrm{Bi}_{2} \mathrm{Br}_{6} \mathrm{~N}_{5} \mathrm{~S}$ : $\mathrm{C}=19.10 ; \mathrm{H}=1.68$; $\mathrm{N}=5.06 ; \mathrm{S}=9.27 \%$. Mid-IR $\left(\mathrm{cm}^{-1}\right): 3169 \mathrm{w}, 1655 \mathrm{w}, 1603 \mathrm{~m}, 1574 \mathrm{~s}$, 1508 m, 1443 m, 1396 w, 1365 m, 1340 w, 1256 m, 1161 m, 1124 s, 1105 m, 1082 m, 1034 m, 1001 w, 897 w, 862 w, 752 s, 721 s, 619 m, 559 w, 484 m, 434 m. UV-Vis (DMSO): $\lambda_{\max }(\log \varepsilon)=256$ (4.70), 293 (4.72) 
and 363 (4.28). Soluble in acetonitrile, acetone, dimethylsulfoxide. $\Lambda_{\mathrm{M}}$ (DMSO): $8.7 \Omega^{-1} \mathrm{~cm}^{2} \mathrm{~mol}^{-1}$.

$\left\{\left[\mathrm{BiBr}_{2}\left(\mu_{2}-\mathrm{Br}\right)(\mathrm{MBZT})_{2}\right]_{2} 2 \mathrm{CH}_{3} \mathrm{OH}\right\}$ (5): A solution of 2-mercaptobenzothiazole $(0.060 \mathrm{~g}, 1.00 \mathrm{mmol})$ in benzene $\left(10 \mathrm{~cm}^{3}\right)$ was added to a solution of bismuth(III) bromide $(0.224 \mathrm{~g}, 0.50 \mathrm{mmol})$ in methanol $\left(10 \mathrm{~cm}^{3}\right)$. The resulting red solution was stirred at $50^{\circ} \mathrm{C}$ for $4 \mathrm{~h}$. The obtained solution was filtered. The clear red solution was kept in darkness at room temperature. Twelve days later, red crystals suitable for single crystal XRD data were obtained.

5: Red crystals; yield $83 \%$; melting point: $189-192^{\circ} \mathrm{C}$; $\mathrm{Mw}=1630.41 \mathrm{~g} / \mathrm{mol}$. Elemental analysis: found: $\mathrm{C}=21.82 ; \mathrm{H}=1.57$; $\mathrm{N}=3.48 ; \mathrm{S}=16.10 \%$; calculated for $\mathrm{C}_{30} \mathrm{H}_{28} \mathrm{Bi}_{2} \mathrm{Br}_{6} \mathrm{~N}_{4} \mathrm{O}_{2} \mathrm{~S}_{8}: \quad \mathrm{C}=21.79$; $\mathrm{H}=1.51 ; \mathrm{N}=3.51 ; \mathrm{S}=16.05 \%$. Mid-IR $\left(\mathrm{cm}^{-1}\right): 3.188 \mathrm{w}, 1601 \mathrm{w}, 1522 \mathrm{w}$, 1491 m, 1423 m, 1356 w, 1331 m, 1281 w, 1250 w, 1153 w, 1130 w, 1078 m, 1022 s, 1007 s, 939 m, 866 m, 176 s, 679 m, 600 m, 561 m, 501 w, 422 m. UV-Vis (DMSO): $\lambda_{\max }(\log \varepsilon)=257$ (4.65) and 327.5 (5.07). Soluble in methanol, ethanol, acetonitrile, acetone, tetrahydrofuran, dimethylsulfoxide. $\Lambda_{\mathrm{M}}$ (DMSO): $23.4 \Omega^{-1} \mathrm{~cm}^{2} \mathrm{~mol}^{-1}$.

\section{X-ray structure determination}

Single crystal XRD diffraction data for $\mathbf{1}, \mathbf{2}$ and $\mathbf{5}$ were collected on an Oxford-Diffraction Supernova diffractometer, equipped with a CCD area detector utilizing $\mathrm{Cu} \mathrm{K \alpha}(\lambda=1.5418 \AA)$ radiation. A suitable crystal was mounted on a Hampton cryoloop with Paratone-N oil and transferred to a goniostat where it was cooled for data collection. The empirical absorption corrections (multiscan based on symmetry-related measurements) were applied using the CrysAlis RED software (Oxford-Diffraction). The structures were solved by direct methods using the SIR2004 (Burla et al., 2005) and refined on $F^{2}$ using the full-matrix least-squares with SHELXL-2014/7 (Sheldrick, 2014). The software packages used were as follows: CrysAlis CCD for data collection (Oxford Diffraction) CrysAlis RED for cell refinement and data reduction (Oxford Diffraction) WINGX for geometric calculations (Farrugia, 1999) and ORTEP for molecular graphics. The non-H atoms were treated anisotropically, whereas the aromatic $\mathrm{H}$ atoms were placed in calculated, ideal positions and refined as riding on their respective carbon atoms. Crystal data for $\mathbf{3}$ and $\mathbf{4}$ were measured on a KUMA KM4CCD four-circle diffractometer (CrysAlis CCD) equipped with a CCD detector using the graphite-monochromated MoKa radiation $(\lambda=0.71073 \AA$ ) $)$. Cell parameters were determined by the least-squares refinement of the diffraction data from 25 reflections (CRYSALIS RED). All data were corrected for the Lorentz-polarization effects and absorption (CRYSALIS RED; Sheldrick, 1990). The structures were solved with direct methods with SHELXS97 (Sheldrick, 1990) and refined by full-matrix leastsquares procedures on $F^{2}$ with SHELXL97 (Sheldrick, 1997). All nonhydrogen atoms were refined anisotropically. The hydrogen atoms were located at the calculated positions and then refined via the 'riding model' with isotropic thermal parameters fixed at 1.2 (1.3 for $\mathrm{CH}_{3}$ groups). The experimental crystallographic data for $\mathbf{1 - 5}$ are provided in Table 3. The structure determination of 2 and 5 ended up in quite large R-factors. This is due to twin crystals. However, despite the high R-factors, the refinement of the data resulted in the safe formulae for these compounds. These are then used for the solution preparation for the biological experiments, which is the main aim of this work.

Supplementary data are available from CCDC, 12 Union Road, Cambridge CB2 1EZ, UK, (e-mail: mailto:deposit@ccdc.cam.ac.uk), on request, quoting the deposition numbers CCDC 1831830 (1), 1831829 (2), 1832427 (3), 1832428 (4) and 1831828 (5).

\section{Biological tests}

Biological experiments were carried in dimethyl sulfoxide Dulbecco's Modified Eagle's Medium solutions (DMEM) DMSO/DMEM $(0.02 \%-0.2 \% \mathrm{v} / \mathrm{v})$ for the complexes 1-5. The stock solutions of the complexes 1-5, (0.01 M) in DMSO were freshly prepared and diluted in a cell culture medium to the desired concentrations $(0.5-30 \mu \mathrm{M})$. The results are expressed in terms of $\mathrm{IC}_{50}$ values, that is, the concentration

Table 3: The experimental crystallographic data for the bismuth(III) bromide complexes 1-5.

\begin{tabular}{|c|c|c|c|c|c|}
\hline & 1 & 2 & 3 & 4 & 5 \\
\hline Empirical formula & $\mathrm{C}_{19} \mathrm{H}_{32} \mathrm{Bi}_{2} \mathrm{Br}_{6} \mathrm{~N}_{8} \mathrm{O}_{2} \mathrm{~S}_{4}$ & $\mathrm{C}_{28} \mathrm{H}_{28} \mathrm{BiBr}_{3} \mathrm{~N}_{8} \mathrm{O}_{2} \mathrm{~S}_{4}$ & $\mathrm{C}_{18} \mathrm{H}_{35} \mathrm{Bi}_{2} \mathrm{Br}_{6} \mathrm{~N}_{9} \mathrm{~S}_{4}$ & $\mathrm{C}_{22} \mathrm{H}_{23} \mathrm{Bi}_{2} \mathrm{Br}_{6} \mathrm{~N}_{5} \mathrm{~S}_{4}$ & $\mathrm{C}_{30} \mathrm{H}_{28} \mathrm{Bi}_{2} \mathrm{Br}_{6} \mathrm{~N}_{4} \mathrm{O}_{2} \mathrm{~S}_{8}$ \\
\hline $\begin{array}{l}\text { Formula weight } \\
(\mathrm{g} / \mathrm{mol})\end{array}$ & 1430.10 & 1085.48 & 1403.18 & 1383.10 & 1630.41 \\
\hline$T(\mathrm{~K})$ & $100(2)$ & $100(2)$ & $100(2)$ & $130(2)$ & $100(2)$ \\
\hline Crystal System & Orthorhombic & Monoclinic & Monoclinic & Monoclinic & Triclinic \\
\hline Space group & $\mathrm{Cmc2}_{1}$ & $P 2_{1} / c$ & $C 2 / c$ & $C 2 / c$ & $P \overline{1}$ \\
\hline$a(\AA)$ & $13.8330(4)$ & $13.8222(4)$ & $23.375(2)$ & $23.225(3)$ & $10.1610(8)$ \\
\hline$b(\AA)$ & $13.6238(4)$ & $17.0677(5)$ & $12.9498(6)$ & $13.2014(6)$ & $10.2461(8)$ \\
\hline$c(\AA)$ & $20.5347(7)$ & $7.7883(2)$ & $15.8095(14)$ & $16.1799(5)$ & $10.6154(10)$ \\
\hline$\alpha(\mathrm{deg})$ & 90 & 90 & 90 & 90 & $90.325(7)$ \\
\hline$\beta$ (deg) & 90 & $98.518(3)$ & $127.987(14)$ & $131.53(3)$ & $91.768(7)$ \\
\hline$\gamma(\mathrm{deg})$ & 90 & 90 & 90 & 90 & $94.071(7)$ \\
\hline$V\left(\AA^{3}\right)$ & $3869.9(2)$ & $1817.10(9)$ & $3771.7(9)$ & $3713.7(18)$ & 1101.83(16) \\
\hline$Z$ & 4 & 2 & 4 & 4 & 1 \\
\hline$\rho$ calcd $\left(\mathrm{g} / \mathrm{cm}^{3}\right)$ & 2.444 & 1.962 & 2.543 & 2.547 & 2.451 \\
\hline$\mu\left(\mathrm{mm}^{-1}\right)$ & 27.184 & 15.860 & 15.927 & 28.274 & 25.700 \\
\hline$R, w R, \mathrm{~S}$ & $0.0263,0.0713,1.057$ & $0.1027,0.2647,1.168$ & $0.0438,0.1147,0.98$ & $0.0439,0.0948,1.02$ & $0.0910,0.2256,1.153$ \\
\hline
\end{tabular}


of drug required to inhibit cell growth by $50 \%$ compared to control, after of $48 \mathrm{~h}$ incubation of the complexes towards cell lines. The cell viability was determined by SRB assay, as previously described (Banti et al., 2016).

\section{Lipoxygenase activity inhibition}

This was performed as previously reported (Xanthopoulou et al., 2008).

Acknowledgements: (a) I.I.O. and M.C.. acknowledge the financial support from The Scientific and Technological Research Council of Turkey (TUBITAK, Project No. 114Z457). (b) CNB and SKH would like to thank the Unit of Bioactivity Testing of Xenobiotics of the University of Ioannina for providing access to their facilities. (c) The International Graduate Program in 'Biological Inorganic Chemistry', which operates at the University of Ioannina within the collaboration of the Departments of Chemistry of the Universities of Ioannina, Athens, Thessaloniki, Patras, Crete and the Department of Chemistry of the University of Cyprus (http://bic.chem.uoi.gr/BIC-En/indexen.html), is acknowledged for the stimulating discussion forum.

\section{References}

Arda, M.; Ozturk, I. I.; Banti, C. N.; Kourkoumelis, N.; Manoli, M.; Tasiopoulos, A. J.; Hadjikakou, S. K. Novel bismuth compounds: synthesis, characterization and biological activity against human adenocarcinoma cells. RSC Adv. 2016, 6, 29026-29044.

Balas, V. I.; Verginadis, I. I.; Geromichalos, G. D.; Kourkoumelis, N.; Male, L.; Hursthouse, M. B.; Repana, K. H.; Yiannaki, E.; Charalabopoulos, K.; Bakas, T.; et al. Synthesis, structural characterization and biological studies of the triphenyltin(IV) complex with 2-thiobarbituric acid. Eur. J. Med. Chem. 2011, 46, 2835-2844.

Banti, C. N.; Papatriantafyllopoulou, C.; Manoli, M.; Tasiopoulos, A. J.; Hadjikakou, S. K. Nimesulide silver metallodrugs, containing the mitochondriotropic, triaryl derivatives of pnictogen; Anticancer activity against human breast cancer cells. Inorg. Chem. 2016, 55, 8681-8696.

Burla, M. C.; Caliandro, R.; Camalli, M.; Carrozzini, B.; Cascarano, G. L.; De Caro, L.; Giacovazzo, C.; Polidori, G.; Spagna, R. SIR2004: an improved tool for crystal structure determination and refinement. J. Appl. Cryst. 2005, 38, 381- 388.

CrysAlis CCD, version 1.171.31.5; Oxford Diffraction Ltd. (release 28-08-2006 CrysAlis171.NET).

CRYSALIS RED, Version 1.171.31.5 (release 28-08-2006 CrysAlis 171.NET); Oxford Diffraction, Ltd.

Farrugia, L. J. WinGX and ORTEP for Windows: an update. J. Appl. Cryst. 1999, 32, $837-838$.
Hadjikakou, S. K.; Antoniadis, C. D.; Hadjiliadis, N.; Kubicki, M.; Binolis, J.; Karkabounas, S.; Charalabopoulos, K. Synthesis and characterization of new water stable antimony(III) complex with pyrimidine-2-thione and in vitro biological study. Inorg. Chim. Acta 2005, 358, 2861-2866.

Haining, J. L.; Axelrod, B. Induction period in the lipoxidase-catalyzed oxidation of linoleic acid and its abolition by substrate peroxide. J. Biol. Chem. 1958, 232, 193-202.

Knapp, M. J.; Klinman, J. P. Kinetic studies of oxygen reactivity in soybean lipoxygenase-1. Biochemistry 2003, 42, 11466-11475.

Li, M.; Li, R. K. Two new bismuth thiourea bromides: crystal structure, growth, and characterization. Dalton Trans. 2014, 43, 2577-2580.

Li, M.; Lu, Y.; Yang, M.; Li, Y.; Zhang, L.; Xie, S. One dodecahedral bismuth(III) complex derived from 2-acetylpyridine N(4)-pyridylthiosemicarbazone: synthesis, crystal structure and biological evaluation. Dalton Trans. 2012a, 41, 12882.

Li, M.-X.; Yang, M.; Niu, J.-Y.; Zhang, L.-Z.; Xie, S.-Q. A ninecoordinated bismuth(III) complex derived from pentadentate 2,6-diacetylpyridine bis((4)N-methylthiosemicarbazone): crystal structure and both in vitro and in vivo biological evaluation. Inorg. Chem. 2012b, 51, 12521-12526.

Lodochnikova, O. A.; Bodrov, A. V.; Saifina, A. F.; Nikitina, L. E.; Litvinov, I. A. A new polymorph of methimazole: Single crystal and powder X-ray diffraction study. J Struct. Chem. 2013, 54, 140-147.

Ohms, U.; Guth, H.; Kutoglu, A.; Scheringer, C. 2-Thiopyridone: X-ray and neutron diffraction study. Acta Cryst. 1982, B38, 831-834.

Oxford Diffraction. CrysAlis CCD and CrysAlis RED; Oxford Diffraction Ltd.: Abingdon, UK, 2008.

Ozturk, I. I.; Hadjikakou, S. K.; Hadjiliadis, N.; Kourkoumelis, N.; Kubicki, M.; Baril, M.; Butler, I. S.; Balzarini, J. Synthesis, structural characterization, and biological studies of new antimony(III) complexes with thiones. The influence of the solvent on the geometry of the complexes. Inorg. Chem. 2007, 46, 8652-8661.

Ozturk, I. I.; Hadjikakou, S. K.; Hadjiliadis, N.; Kourkoumelis, N.; Kubicki, M.; Tasiopoulos, A. J.; Scleiman, H.; Barsan, M. M.; Butler, I. S. New antimony(III) bromide complexes with thioamides: synthesis, characterization, and cytostatic properties. Inorg. Chem. 2009, 48, 2233-2245.

Ozturk, I. I.; Filimonova, S.; Hadjikakou, S. K.; Kourkoumelis, N.; Dokorou, V.; Manos, M. J.; Tasiopoulos, A. J.;. Barsan, M. M.; Butler, I. S.;. Milaeva, E. R.; et al. Structural motifs and biological studies of new antimony(III) iodide complexes with thiones. Inorg. Chem. 2010, 49, 488-501.

Ozturk, I. I.; Kourkoumelis, N.; Hadjikakou, S. K.; Manos, M. J.; Tasiopoulos, A. J.; Butler, I. S.; Balzarini, J.; Hadjiliadis, N. Interaction of antimony(III) chloride with thiourea, 2-mercapto5-methyl-benzimidazole, 3-methyl-2-mercaptobenzothiazole, 2-mercaptopyrimidine, and 2-mercaptopyridine. J. Coord. Chem. 2011, 64, 3859-3871.

Ozturk, I. I.; Banti, C. N.; Manos, M. J.; Tasiopoulos, A. J.; Kourkoumelis, N.; Charalabopoulos, K.; Hadjikakou, S. K. Synthesis, characterization and biological studies of new antimony(III) halide complexes with $\omega$-thiocaprolactam. J. Inorg. Biochem. 2012a, 109, 57-65.

Ozturk, I. I.; Metsios, A. K.; Filimonova-Orlova, S.; Kourkoumelis, N.; Hadjikakou, S. K.; Manos, E.; Tasiopoulos, A. J.; Karkabounas, S.; Milaeva, E. R.; Hadjiliadis, N. Study on single crystal struc- 
ture of the antimony(III) bromide complex with 3-methyl-2-mercaptobenzothiazole and biological activity of some antimony(III) bromide complexes with thioamides. Med. Chem. Res. 2012b, 21, 3523-3531.

Ozturk, I. I.; Urgut, O. S.; Banti, C. N.; Kourkoumelis, N.; Owczarzak, A. M.; Kubicki, M.; Charalabopoulos, K.; Hadjikakou, S. K. Synthesis, structural characterization and cytotoxicity of the antimony(III) chloride complex with N,N-Dicyclohexyldithiooxamide. Polyhedron 2013, 52, 1403-1410.

Ozturk, I. I.; Banti, C. N.; Kourkoumelis, N.; Manos, M. J.; Tasiopoulos, A. J.; Owczarzak, A. M.; Kubicki, M.; Hadjikakou, S. K. Synthesis, characterization and biological activity of antimony(III) or bismuth(III) chloride complexes with dithiocarbamate ligands derived fromthiuram degradation. Polyhedron 2014a, 67, 89-103.

Ozturk, I. I.; Urgut, O. S.; Banti, C. N.; Kourkoumelis, N.; Owczarzak, A. M.; Kubicki, M.; Hadjikakou, S. K. Synthesis, structural characterization and cytostatic properties of N,N-dicyclohexyldithiooxamide complexes of antimony(III) halides ( $\mathrm{SbX}_{3}, \mathrm{X}: \mathrm{Br}$ or I). Polyhedron 2014b, 70, 172-179.

Ozturk, I. I.; Yarar, S.; Banti, C. N.; Kourkoumelis, N.; Chrysouli, M. P.; Manoli, M.; Tasiopoulos, A. J.; Hadjikakou, S. K. QSAR studies on antimony(III) halide complexes with $\mathrm{N}$-substituted thiourea derivatives. Polyhedron 2017, 123, 152-161.

Popović, Z.; Matković-Ćalogović, D.; Pavlović, G.; Soldin Ẑ.; Giester, G.; Rajić, M.; Vikić-Topić, D. Preparation, thermal analysis and spectral characterization of the 1:1 complexes of mercury(II) halides and pseudohalides with 3,4,5,6-tetrahydropyrimidine2-thione. Crystal structures of Bis(3,4,5,6-tetrahydropyrimidine2-thione-S)mercury(II) tetrachloro and tetrabromomercurate(II). Croat. Chem. Acta 2001, 74, 359-380.

Poyraz, M.; Banti, C. N.; Kourkoumelis, N.; Dokorou, V.; Manos, M. J.; Simčič, M.; Golič-Grdadolnik, S.; Mavromoustakos, T.; Giannoulis, A. D.; Verginadis, I. I.; et al. Synthesis, structural characterization and biological studies of novel mixed ligand $\mathrm{Ag}(\mathrm{I})$ complexes with triphenylphosphine and aspirin or salicylic acid. Inorg. Chim. Acta 2011, 375, 114-121.

Ravikuma, K.; Mohan, K. C.; Bidyasagar, M.; Swamy, G. Y. S. K. Crystal structure of 2-mercaptobenzimidazole and bis[2-mercaptobenzimidazole]dichlorocobalt(II). J. Chem. Crystallogr. 1995, 25, 325-329.

Samuelsson, B.; Dahlen, S. E.; Lindgren, J.; Rouzer, C. A.; Serhan, C. N. Leukotrienes and lipoxins: structures, biosynthesis, and biological effects. Science 1987, 237, 1171-1176.

Sheldrick, G. M. Phase annealing in SHELX-90: direct methods for larger structures. Acta Crystallogr. 1990, A 46, 467-473.

Sheldrick, G. M. SHELXL-97, Program for the Refinement of Crystal Structures; University of Göttingen: Göttingen, Germany, 1997.
Sheldrick, G. M. SHELXL-2014/7, Program for Refinement of Crystal Structures; University of Göttingen: Germany, 2014.

Shpakovsky, D. B.; Banti, C. N.; Beaulieu-Houle, G.; Kourkoumelis, N.; Manoli, M.; Manos, M. J.; Tasiopoulos, A. J.;. Hadjikakou, S. K.; Milaeva, E. R.; Charalabopoulos, K.; et al. Synthesis, structural characterization and in vitro inhibitory studies against human breast cancer of the bis-(2,6-di-tert-butylphenol)tin(IV) dichloride and its complexes. Dalton Trans. 2012, 41, 1456814582.

Srinivas, K.; Suresh, P.; Babu, C. N.; Sathyanarayana, A.; Prabusankar, G. Heavier chalcogenone complexes of bismuth(III) trihalides: potential catalysts for acylative cleavage of cyclic ethers. RSC Adv. 2015, 5, 15579-15590.

Srinivas, K.; Sathyanarayana, A.; Babu, C. N.; Prabusankar, G. Bismuth(III)dichalcogenones as highly active catalysts in multiple C - C bond formation reactions. Dalton Trans. 2016, 45, 5196-5209.

Urgut, O. S.; Ozturk, I. I.; Banti, C. N.; Kourkoumelis, N.; Manoli, M.; Tasiopoulos, A. J.; Hadjikakou, S. K. New antimony(III) halide complexes with dithiocarbamate ligands derived from thiuram degradation: the effect of the molecule's close contacts on in vitro cytotoxic activity. Mater. Sci. Eng. C 2016a, 58, 396-408.

Urgut, O. S.; Ozturk, I. I.; Banti, C. N.; Kourkoumelis, N.; Manoli, M.; Tasiopoulos, A. J.; Hadjikakou, S. K. Addition of tetraethylthiuram disulfide to antimony(III) iodide; synthesis, characterization and biological activity. Inorg. Chim. Acta 2016b, 443, 141-150.

Xanthopoulou, M. N.; Hadjikakou, S. K.; Hadjiliadis, N.; Milaeva, E. R.; Gracheva, J. A.; Tyurin, V. Yu.; Kourkoumelis, N.; Christoforidis, K. C.; Metsios, A. K.; Karkabounas, S.; et al. Biological studies of new organotin(IV) complexes of thioamide ligands. Eur. J. Med. Chem. 2008, 43, 327-335.

Yang, N.; Sun, H. Biocoordination chemistry of bismuth: recent advances. Coord. Chem. Rev. 2007, 251, 2354-2366.

Yarar, S.; Ozturk, I. I.; Banti, C. N.; Panagiotou, N.; Papatriantafyllopoulou, C.; Manoli, M.; Manos, M. J.; Tasiopoulos, A. J.; Hadjikakou, S. K. Synthesis, characterization and cytostatic properties of bismuth(III) chloride complexes with heterocyclic thioamides; A survey for structure activity relationship. Inorg Chim Acta 2018, 471, 23-33.

Zhang, N.; Tai, Y.; Li, M.; Ma, P.; Zhao, J.; Niu, J. Main group bismuth(III), gallium(III) and diorganotin(IV) complexes derived from bis(2-acetylpyrazine)thiocarbonohydrazone: synthesis, crystal structures and biological evaluation. Dalton Trans. 2014, 43, 5182-5189.

Supplementary Material: The online version of this article offers supplementary material (https://doi.org/10.1515/mgmc-2018-0035). 